\title{
Fashion Meets Twitter: Does the Source Matter? Perceived Message Credibility, Interactivity and Purchase Intention
}

Yijia Wang

West Virginia University

Follow this and additional works at: https://researchrepository.wvu.edu/etd

\section{Recommended Citation}

Wang, Yijia, "Fashion Meets Twitter: Does the Source Matter? Perceived Message Credibility, Interactivity and Purchase Intention" (2014). Graduate Theses, Dissertations, and Problem Reports. 335.

https://researchrepository.wvu.edu/etd/335

This Thesis is protected by copyright and/or related rights. It has been brought to you by the The Research Repository @ WVU with permission from the rights-holder(s). You are free to use this Thesis in any way that is permitted by the copyright and related rights legislation that applies to your use. For other uses you must obtain permission from the rights-holder(s) directly, unless additional rights are indicated by a Creative Commons license in the record and/ or on the work itself. This Thesis has been accepted for inclusion in WVU Graduate Theses, Dissertations, and Problem Reports collection by an authorized administrator of The Research Repository @ WVU. For more information, please contact researchrepository@mail.wvu.edu. 
Fashion Meets Twitter: Does the Source Matter? Perceived Message Credibility, Interactivity and Purchase Intention

\author{
Yijia Wang \\ Thesis submitted to the \\ Reed College of Media \\ at West Virginia University \\ in partial fulfillment of the requirements \\ for the degree of
}

Master of Science in

Journalism

Geah Pressgrove, Ph.D., Chair

Elizabeth Oppe, Ph.D.

James Ebel, MBA.

Elizabeth Cohen, Ph.D.

Department of Journalism

Morgantown, West Virginia

2014

Keywords: source credibility; interactivity; purchase intention; fashion industry; Twitter

Copyright 2014 Yijia Wang 


\begin{abstract}
Fashion Meets Twitter: Does the Source Matter? Perceived Message Credibility, Interactivity and Purchase Intention
\end{abstract}

\begin{abstract}
Yijia Wang
Through an online survey, this study explored the perceived source credibility of fashion industry Twitter messages with varying message sources (the brand itself, celebrity endorser, friend/acquaintance). Online interactivity and purchase intention of potential customers were also assessed to examine if a particular message source and its credibility increase the likelihood of online engagement with the message and customers' intention to purchase.

Findings indicate that of all source types, brands were perceived as most credible overall, as well as on dimensions of expertise, character, and attractiveness. Furthermore, there was a higher probability of respondents searching for additional information based on a tweet from a brand. In terms of purchase based on Twitter messages, respondents were most motivated based on the affordability, value and the ability of the fashion item to compliment their personal style. Conversely, celebrity endorsers scored lowest in every variable, including credibility, interactivity and purchase intention, which might provide some insight into social media celebrity endorsement for fashion brands and designers.
\end{abstract}

These findings highlight the value of source selection in Twitter messaging for the fashion industry, as well as the content of the messages posted in this forum. Optimization and leveraging of messages based on these findings should lead to better return on investment as measured by online engagement and purchase intention. 


\section{Table of Contents}

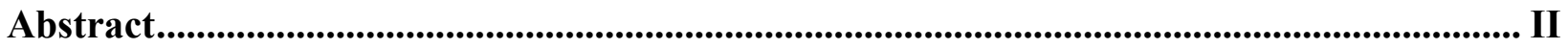

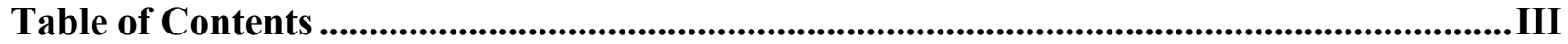

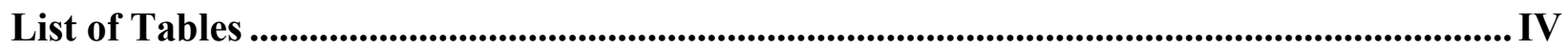

Chapter 1: Introduction ........................................................................................................................1

1.1 The World Wide Web, New Media and Twitter................................................................. 1

1.2 The Fashion Industry .......................................................................................................................... 1

1.3 Technology, Communication \& Fashion ............................................................................................ 2

Chapter 2: Literature Review .........................................................................................................5

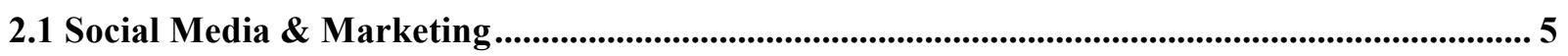

2.2 Twitter Source Type: Opinion Leaders ............................................................................................... 7

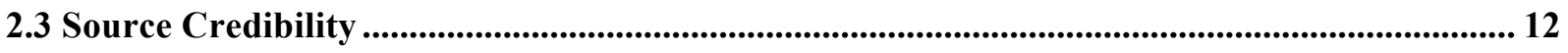

2.4 Interactivity \& Online Message Engagement.................................................................................... 16

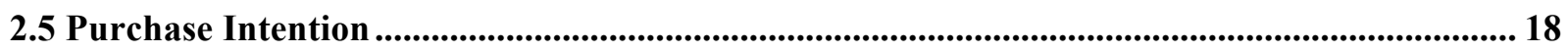

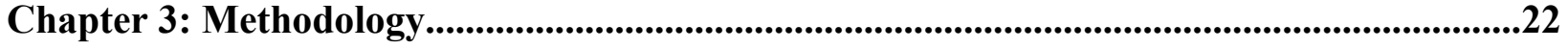

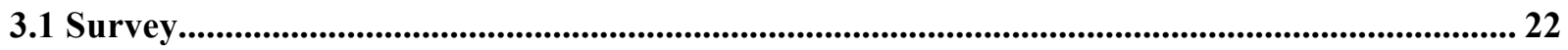

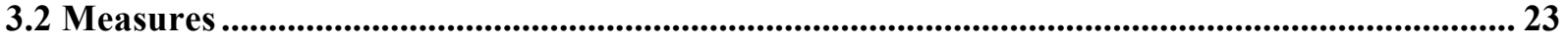

3.3 Sample .................................................................................................................................................... 26

3.4 Analysis Process .................................................................................................................................. 26

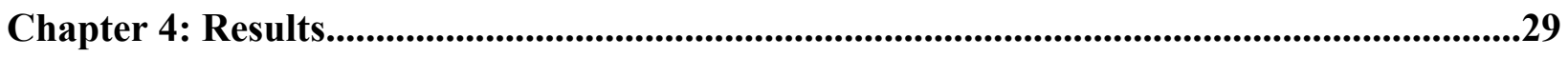

Chapter 5: Discussion .....................................................................................................................37

5.1 Findings and Implications ................................................................................................................. 37

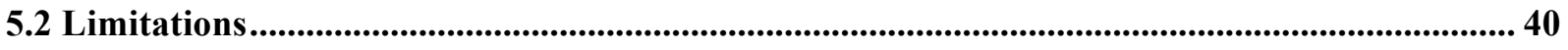

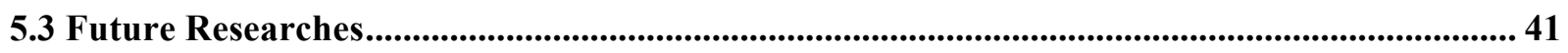

Chapter 6: Conclusion ..............................................................................................................................43

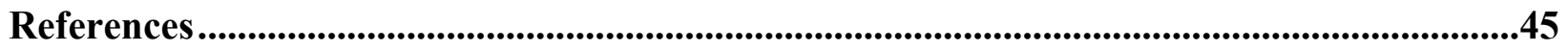

Appendices ...............................................................................................................................................58

Appendix A: IRB Cover Letter ....................................................................................................5

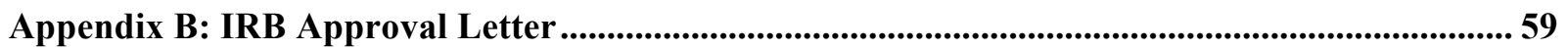

Appendix C: Informed Consent Statement .........................................................................................60

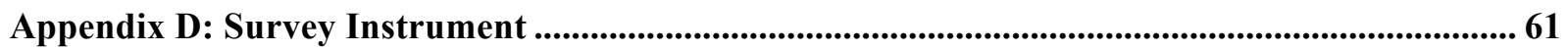




\section{List of Tables}

Figure 1 Research Questions, Hypotheses and Associated Statistics Tests ...........................28 Table 1 Means, Standard Deviations and Reliability Coefficients for Credibility by Source

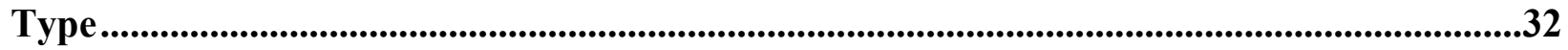

Table 2 Mean Scores for Interactivity by Source Type...............................................................34

Table 3 Mean Scores for Purchase Intention by Source Type..................................................36 


\section{Chapter 1: Introduction}

\subsection{The World Wide Web, New Media and Twitter}

In the last decade, the World Wide Web has emerged as a medium for users to not only learn about the day's news, share information, connect with friends and learn from opinion leaders; it has also become a platform for consumer brands to market their wares. Up to 84 percent of all Americans now expect the Internet to provide them information that they need on different issues (Rainie, \& Duggan, 2014). In particular, since the creation of Facebook in 2004, launch of YouTube in 2005 and birth of Twitter in 2006, social networks have become an important part of the corporate marketing mix. The explosion of content creation and sharing however, has led to challenges for brand marketers and communicators. One such industry struggling with how to effectively integrate the fast-paced social communication possibilities in its marketing campaigns is fashion.

While the ability to rapidly connect with stakeholders and potential consumers provides many opportunities, brands and designers wishing to engage on these platforms are challenged with knowing the appropriate spokesperson for disseminating their message, how to engage consumers and if these messages are stimulating purchase intention. Thus, the primary aim of this study is to investigate the perceptions of the credibility of the source of social media messages in the fashion industry and how different sources might garner different behavioral outcomes.

\subsection{The Fashion Industry}

The fashion industry, with the estimated revenues of $\$ 500$ billion worldwide, is considered 
the fourth largest industry globally (Helmore, 2010), thus making it an important cog in the national economy. Contributing to the size of the fashion market is its maturity and expanded scope of its target market leading to a drastic growth in the number of customers. According to Bourdieu (1979), fashion objects regarded as legitimate works of art produce subtle differences that give rise to ranking between and within social groups. While designer and price point may lead to some social differences, increased acceptance of individual expression has reduced such imparities. In fact, according to Lipovetsky (1987), since the explosion of Chanel's Mademoiselle in 1920, the fashion world has become a centerless industry that no longer belongs to the elite class, but expands to all social classes.

The combined growth of the consumer market and focus on individual expression has led to many idiosyncratic trends driven by groups organized around opinion leaders (Vernette, 2004). In the fashion industry, opinion leaders may be more formally hired by a fashion house as a spokesperson; the designer or brand itself; or more informally a consumer unknown to the brand, yet still influential in their circle of reference. Thus it is meaningful to look at the fashion industry while studying the source credibility of a marketing endorsement.

\subsection{Technology, Communication \& Fashion}

From 2000 to 2012, the number of Internet users increased by an overwhelming 566\% (Internet World Stats, 2012). More recently, the popularity of social media sites has increased. According to a recent Pew Research study, $73 \%$ of online adults are now using some form of social media (Duggan \& Smith, 2013). Further, the number of people that follow brands on social media sites more than doubled between 2010 and 2012 (Brown, n.d.). The process is 
simple. Technology-based communication platforms encourage customers to interact with brands. In turn, these interactions build the brand by increasing awareness, involvement and engagement. This engagement is intended to increase brand recall and stimulate purchase. The question becomes, however, what factors lead to success.

Perhaps in part because of their highly visual products, fashion brands have been early adopters of social media (Allen, 2013), with the first brands launching social media strategies in 2009 (Mohr, 2013). The large number of users and high volume of information communicated online, however, is challenging the traditional process of fashion brand marketing. Whereas traditional fashion media sources, such as stories in glossy magazines and newspaper columns written by industry insiders, used to serve as the primary independent source of unbiased information, social media platforms have now made it possible for anyone to share their opinions, thoughts and interests on today's fashion trends. This shift makes perceptions of the source of a social media message a key issue of concern for marketers.

Twitter, a "real-time information network that connects you to the latest information about what you find interesting" (Twitter, n.d.), has emerged as a leading online platform for brands and celebrities alike to market themselves. This is due in part to recent research indicating that Twitter helps brands to gain more exposure and strengthen relationships with customers (Kim, \& Ko, 2012). Conversely, recent research has demonstrated that although 75 percent of female social media users indicate that the brands and products their friends use influence their purchase decision, they indicated that Twitter was not a major influencer on their fashion decisions (Rosner \& Scuncio, 2013). This indicates that, although consumers are connecting with brands 
online, the fashion industry is not yet successfully using platforms like Twitter to engage purchase intention. One reason for this may be the source of the message and its perceived credibility.

Thus, the purpose of this study is to better understand the importance of the source of a fashion industry message on Twitter in terms of stimulating engagement and purchase intention. To this end, the study has three primary objectives. First the author will explore perceptions of credibility based on varying message sources on Twitter (the brand itself, celebrity endorser, friend/acquaintance). Second, online interactivity will be assessed to examine if a particular message source increases the likelihood of engagement with the message online (e.g. reTweet, comment, favorite). Finally, the author will investigate if different message sources have greater predictive value in terms of a consumer's intention to purchase.

It is anticipated that these findings will lay the groundwork for future studies of other consumer-focused industries, as well as explorations of the role of message source in social media. This study may also help to advance the current knowledge of interactive marketing on Twitter, which can be applied in social media marketing in the future. 


\section{Chapter 2: Literature Review}

According to a Reuters' report (2009), the Internet has become the most popular source of information and the preferred choice for news, ahead of television, newspapers and radio in the United States, and information seeking has become the strongest motivation of Internet use. However, the Internet differs from other channels used for information dissemination in key ways that can affect its reliability, and credibility as an information source.

The Internet's structure, designed specifically not to be centrally controlled, best explains the popular phrase "information wants to be free" (Brand, 1987, p. 49), which describes the free-flow of information that takes place over the Internet. Indeed, on the Internet anyone can be an author. Beacham (1995, p.516) holds that "the Internet represents the information revolution ... one that removes the governmental and corporate filters that have so long been in place with traditional mass media." This information freedom, however, also introduces an increased potential for error or decreased confidence in the source.

\subsection{Social Media \& Marketing}

The growth of new media, in particular social media, in the first decade of the twenty-first century has witnessed a transformation of marketing communication. Social media is a term used to describe a variety of channels that are built on the idea of collaborative creation and dissemination of content. Derived from the fundamental principle of Web 2.0, social media channels focus on administrating collective intelligence (O'Reilly and Battelle, 2009), and refer to some form of computer-mediated communication, namely common applications and services such as blogs, video sharing, social networking and podcasting, that allow users to create and 
exchange information (Kaplan and Haenlein, 2012).

Recognizing the promise of social media, a 2010 study found that $94 \%$ of marketing executives indicated that they expect to spend more on social media over the following three years (Busby et al., 2010). Further, a study by DEI Worldwide (2008) indicates that $70 \%$ of consumers have visited social media sites to get information, $49 \%$ of these consumers have made a purchase decision based on the information they found through the social media sites and $60 \%$ said they were likely to use social media sites to pass along information to others online. This report posits that companies not engaging in social media as part of their online marketing strategy are missing an opportunity to reach consumers.

One of the most popular forms of social media is microblogging, with Twitter (www.twitter.com) being the most prevalently used platform. With a total number of $645,750,000$ active registered Twitter users, an average of 2.1 billion tweets are shared every day (Internet World Stats, 2012). Twitter's identity as a source for information is rapidly becoming more prominent, and the service has been recognized as a useful news and current events tool (Kwak, Lee, Park, \& Moon, 2010). The popularity of this platform may partly be related to the relative ease of use and speed of sharing in short 140 character posts.

As a means to build relationship and stimulate purchase intention, fashion brands have tilted their eyes toward social media. It has been said that Twitter has become an important part of fashion brands marketing because of the potential to provide accessible, personal, engaging content (Orcutt, 2012). In the fashion industry, marketing communication using social media like Twitter has already been evaluated as a business promotion tool that can have a dramatic impact 
on the reputation of the brand (Kim \& Ko, 2012). To date, however, research has not investigated the power of an opinion leader endorsement in this context. This study seeks to fill this gap in the literature.

\subsection{Opinion leaders}

Opinion leaders are an influential force whose views are respected within a community, thus helping to shape the attitudes, beliefs, motivations and behaviors of others around them (Valente, \& Pumpuang, 2007). According to Rogers (1971), the force of an opinion leader lies in the degree to which an individual can influence informally other individuals' attitudes or behavior in a desired way, such as motivating consumers to purchase a particular product or brand.

From a marketing perspective, opinion leaders are similar to product champions, who are described as individuals who emerge in an organization (Chakrabarti, 1974) and make a "decisive contribution to the innovations by actively and enthusiastically promoting its progress through the critical organizational stages" (Achilladelis et al., 1971, p.14). Further, opinion leaders may not be the earliest proponents of new ideas, but may tend to monitor the atmosphere

of opinion and apply their influence when the advantages of the new ideas are obvious or when it is clear that consensus is about to change (Valente, \& Pumpuang, 2007). From a communication perspective, opinion leadership is most often applied in the diffusion of innovation field, which attempts to explain how new ideas spread within and between communities (Rogers, 1971). Katz and Lazarsfeld (1955) put forward the two-step flow communication theory, which holds that most people form their opinions under the influence of opinion leaders, who in turn are influenced by the mass media. According to this model, ideas flow from mass media to opinion 
leaders, and from them to a wider population.

From an organizational management perspective, leaders can be classified into formal and informal leaders. Formal leaders are members of an organization who have been given authority by virtue of their position to influence other members of an organization to achieve organizational goals. An informal leader has no formal organizational authority to influence others, but possesses skills and talent to influence and lead others (Hiray, 2007).

In the context of this study, opinion leaders are conceived as formal and informal online voices that appear in the Twitter feed of a potential consumer. These speakers are active proponents of a particular fashion, brand or designer. Through their commentary, these online voices act as trendsetters sharing messages about what is vogue. Formal opinion leaders refer to people who work for the brand or organization, or people who are paid by the organization to promote products or service of the brand or organization. In the context of this study there are two forms of formal opinion leaders. First are the brands or designers themselves, who for profit seeking motives, regularly post messages about their own fashion. Next are celebrity spokespersons, either paid or unpaid, who serve as brand champions who enthusiastically endorse designers or fashion houses in their online posts.

Informal opinion leaders are people who are not paid for endorsement but still promote a product or service of a brand or organization. On Twitter, informal opinion leaders refer to people who are not paid for promoting but post comments that could be construed as endorsements. These individual may not be early trendsetters, but are influential within their own follower base as mavens of fashion. An example would be a Twitter user who tweets about a 
new style he or she likes, or retweets the post of a brand or celebrity.

\section{Brands as Formal Opinion Leaders}

The concept of brand has become an important marketing component and a rich source of information to consumers. Brands offer a means of identification and personality for an otherwise basic consumer commodity. In addition, branding is a sign of quality and can be used to secure competitive advantage and increased financial returns when there is high customer loyalty (Batra, \& Homer, 2004). Products evolved into brands in order to create differentiation in increasingly competitive markets by offering customers something extra over and above the functional attributes and associated potential benefits.

Brands are an important source of information in the fashion industry. Take for instance the popularity of Fashion Week, where designers from around the world unveil their new designs for the upcoming season. Trendsetters, media writers, bloggers and the fashion focused, converge on these shows to understand the new trends and get a sneak peek at what the fashion of the next season will be. Whereas other opinion leaders (e.g. celebrities) may communicate about fashion trends by commenting, endorsing or reviewing; brands create, influence and often set new trends.

Designers, fashion houses and retailers as varied as Gucci, Target, Urban Outfitters, Louis Vuitton and Rachel Roy are examples of brands with their own Twitter official accounts used for marketing. These brands are rushing into Twitter and reshaping not only interpersonal communication, but also how fashion products are marketed and sold (Stephenson, 2009). Demonstrating the potential success of a brand's ability to reach consumers on Twitter, Dior has more than 4 million followers, with Chanel close on its heels in number of followers (Bennett, 
2014).

Celebrities as Formal Opinion Leaders.

According to Engel, et al (1995), opinion leaders directly or indirectly have a major impact on their immediate environment. In the fashion industry, the marriage of celebrity and fashion is very obvious in Hollywood, and particularly on the red carpet where fashion designers court film stars and celebrities to wear their brands at premiers and award shows such as the Oscars (Carroll, 2008). In fact, celebrities have been described as the "anonymous models" (McCraken, 1989). In 2003 , the anonymity began to disappear as a new wave of brand campaigns emerged with celebrities as the fashion-forward focus (Carroll, 2005). The celebrity fashion focus may have started with Gap, but it soon expanded to other fashion brands including Mulberry, Marc Jacobs and Asprey (Carroll, 2009).

Strategic marketing communicators select these high-visibility spokespersons to associate their brands personality with the popularity of the celebrity. When consumers purchase goods, they search for relevant information in the environment they live in. Fashion marketers anticipate that the prominence of the celebrity endorser will lead to an equally trendy brand perception leading to increased sales.

Although celebrity spokespersons have been a part of marketing for decades, Twitter is now revolutionizing the way these endorsements work. According to Gladwell (2000), a small group of people with a massive following has the power to influence purchase decisions and behavior. Accordingly, because of their volume of followers on sites like Twitter, celebrities provide a channel for this powerful mass transfer of information. For example, Singer Ray J urged his 
600,000 followers to see the horror movie "Saw 3D." Lamar Odom, the New York Knicks

forward, tweeted to his nearly 2 million followers about hip-hop artist and entrepreneur Jay-Z's book "Decoded" (Rexrode, 2011). The hope is that if an influential celebrity tweets an endorsement about a product, they will inspire other people to know about and buy the product. Ultimately, a trend begins and it'll be much easier for the product or brand to gain social name recognition (Roat, 2012).

\section{Friends/Acquaintances as Informal Opinion Leaders}

Unlike in days gone by where brands were often the only senders of messages, today's communication process has become increasingly multidirectional (Kang, 2010). In fact, Ohanian (1991) holds that people usually regard their good friends as a more credible source of information even though sales people may have more knowledge and skills in a specific field. Nielsen's Global Trust in Advertising report (2012) indicates that 92 percent of consumers claim they trust recommendations from friends and family above all other forms of advertising. According to Baar (2013), given that recommendations from friends and family hold the highest trust value, marketers would be wise to incentivize customers to provide positive feedback and/or referring friends to the company. This kind of recommendation is closely related to word of mouth advertising (WOM).

As an important kind of personal communication, WOM is used to describe the unpaid spread of a positive marketing messages from person-to-person (Marketing Made Simple, n.d.), including typical friend/acquaintance recommendation or positive reviews on some products or brands as mentioned above. This spread of information can take place orally, or be transmitted 
via any communicative means such as social media. According to Arndt (1967), WOM is one of the most influential sources of marketplace information for consumers. While, WOM is difficult to control and measure, it is said to be highly influential in purchase decisions (Marketing Made Simple, n.d.). However, at the viral speed that messages travel on the Internet, it is difficult to discern if the information is good or bad (Mohr, 2013). Even though this type of communication starts in person to person, it may still cause large-scale, viral communication due to the availability to the mass and immediacy of Twitter (Jasen, Zhang, Sobel, \& Chowdury, 2009). Thus the friend-to-friend personal communication model is a very important component of understanding perception and influence of the sources of online messages.

\subsection{Source Credibility}

Despite Twitter's popularity, convenience and the promise of the free flow of information, there are also some disadvantages to the platform as a mechanism for marketing communication. One such disadvantage is the relative lack of gatekeeping of information compared to traditional media. This lack of mediation between information source and receiver leads to the necessity of consumers making their own judgments of the information they receive. Further, previous research has demonstrated that credibility is more than the perceptions of passive receivers. Today the public is much more active in choosing communication mediums (Rubin, 2002). They tend to rely on those media channels that they perceive as more credible (Johnson \& Kaye, 1998). Thus, how people make judgments about source credibility is extremely important in learning the utility of Twitter-based information as a marketing tool. Specifically, given the increased use of social media marketing in the fashion industry, and consumers' reliance on such channels to find 
information, this study seeks to investigate perceptions of source credibility on Twitter from the aforementioned opinion leaders.

\section{Source Credibility Defined}

Information provided in newer, online channels often suffers from a relative lack of professional gatekeepers to monitor content, and thus, lacks some of the traditional markers used to determine source credibility. Indeed, online, the gatekeeping function seems to shift from producers of content to consumers of content (Flanagin, \& Metzger, 2000). This leaves consumers responsible for making decisions about the perceived credibility of information they consume online.

Credibility is an important characteristic of information sources, as the message source may play an important role in forming public trust perceptions (Chaiken \& Maheswaran, 1994). According to Yoon (2005), source credibility may be defined as a person's believability as a source of information or the degree to which information from a source is perceived as accurate, fair, unbiased and trustworthy. In the context of this study, source credibility is defined as “judgments made by a perceiver ... concerning the believability of a communicator" (O'Keefe, 2002, p. 181).

To assess perceptions of credibility of the source of a Twitter message, this study draws on three measures. First, according to McCroskey (1966), credibility is comprised of dimensions of authoritativeness and character. His research indicates that in persuasive communication, authoritativeness accounts for 47 percent of variance in credibility, while character accounts for 29 percent of variance. More recently, however, Ohanian (1990) advanced, that authoritativeness 
could also be construed as expertise, which is discussed in detail below. Therefore, in order to increase parsimony, this study uses only the character dimension from McCroskey's model of credibility.

The second approach to measuring source credibility is focused on a 2010 research paper from the Institute for Public Relations. In this study, Kang (2010) developed a two-factor measure for assessing source and content credibility for blogs. As this study does not address the content of messages on Twitter, only the source credibility of bloggers factor will be considered. According to Kang's research (2010) a blogger's credibility is based on metrics such as influence, passion and transparency.

The third approach to measuring source credibility classifies the construct into three dimensions: expertise, trustworthiness, and attractiveness. In this context, expertise is defined as the extent to which a communicator is perceived to be a valid source of information (Hovland, Janis and Kelley, 1953), that the knowledge that the communicator seems to possess supports the statements made in the endorsement (Ohanian, 1991) and the perceived ability of the source to make valid proposition (McCracken, 1989). Trustworthiness refers to the consumer's confidence in the source for providing objective and trustworthy information (Giffin, 1972) and the perceived willingness of the source to make valid propositions (McCraken, 1989).

The increasing use of celebrities as endorsers of products and services has also led to attractiveness as an important dimension of source credibility (Patzer, 1983). Attractiveness of the source seems an important measure of credibility in an industry focused on personal expressions of beauty. Research in advertising and communication suggests that physical 
attractiveness is an important index in an individual's initial judgment of another individual (Baker, \& Churchill, 1977; Chaiken, 1979). It is also demonstrated that physically attractive communicators are more successful in changing opinions than those unattractive communicators (Chaiken, 1979; Dion and Berscheid, 1972).

There are two central models that discuss the persuasive qualities of these dimensions of source credibility: the source credibility model and the source attractiveness model. The source credibility model is established on the basis of social psychology (Hovland, Janis, \& Kelley, 1953). The Hovland version of the model contends that message's effectiveness depends on the expertise and trustworthiness of the source as mentioned above (Hovland, Janis, \& Kelley, 1953). This model posits that sources showing expertise and trustworthiness are credible and persuasive.

The source attractiveness model, which is also based on social psychological research, argues that a message's effectiveness depends mainly on the familiarity, likability, and/or similarity of the source (McGuire, 1985.) Thus, the McGuire holds that sources that are known, liked by, and/or similar to the consumer are attractive and persuasive. Based on the literature, it is anticipated that all three opinion leader types will be seen as credible sources of fashion messages on Twitter on the measures of expertise, character, attractiveness, trustworthiness and effectiveness. Thus, the following hypotheses are advanced.

H1: Official messages from the brand or designer will be viewed as credible sources of fashion messages on Twitter.

H2: Celebrity endorsers will be viewed as credible sources of fashion messages on Twitter. 
H3: Informal opinion leaders (e.g. friends/acquaintances) viewed as credible sources of fashion messages on Twitter.

While previous literature provides early evidence that each of these opinion leader types will be viewed as credible from the perspective of the consumer, it is not clear which source will be viewed as the most credible. Therefore, the first research question seeks to explore this relationship.

RQ1: What source (official brand/designer, celebrity endorser, informal opinion leader) will be viewed as the most credible source of fashion messages on Twitter?

\subsection{Interactivity \& Online Message Engagement}

\section{Interactivity Defined}

Research indicates that increased interactivity is closely related to higher comprehension and more information processing (Sicilia et al., 2005). Despite increasing interests in interactive communications, the consensus of a clear definition of interactivity is not made (Kim \& McMillan, 2008; McMillan, 2006). Recent research, focused primarily on websites, offer two interpretations of interactivity. The first interpretation is termed the "interpersonal view" (Macias, 2003), which regards interactivity as involving communication between individuals and organizations, ranging from non-interactive, one-way communications, to reactive communications and fully interactive communications (Sundar et al., 2003). The second interpretation of interactivity focuses on the structure of the medium, and defines interactivity as "the extent to which users can participate in modifying the messages they receive" (Steuer, 1992, p. 84). This form of interactivity is summarized by Hoffman and Novak (1996) as "machine 
interactivity." In this interpretation, websites are classified as providing different interactivity levels, depending on the features of links, chats and so on (Sicilia et al., 2005). Twitter, according to Burton and Soboleva (2011), can provide both types of interactivity as it allows both interpersonal interactivity (by exchange of messages between an individual and organization and referencing others' messages) and also machine interactivity (by usage of hyperlinks, images and so on).

Social media are virtual platforms for interactivity and information exchange (Perlmutter, 2008). The function of interactivity is crucial to Internet marketing communication (Kim, Spielmann, \& McMillan, 2011) making it easier for brands to build relationships with customers (Rust and Espinoza, 2006). Recent research has begun to explore some of the factors that may lead to increased interactivity on websites, blogs and social media. This body of inquiry indicates that interactivity is influenced by functions such as the interdependence of message sender and respondents (Guillory \& Sundar, 2008), interest in a topic (Smith, 2010; Sundar, Kalyanaraman, \& Brown, 2003) and issue alliance (like retweets, comment, favorite applications) (Smith, 2010). Other research focused on the platform itself found that users' perceptions of interactivity of a website had a significant positive influence on online trust, as well as attitude toward the website (McMillan, et al., 2003; Wu et al., 2010).

With reference to interactivity on Twitter, research has also begun to explore the potential for the platform to engage users. This line of inquiry ranges from qualitative analysis of user involvement related to supporting relief efforts following the 2010 Haiti earthquake (Smith, 2010), a content analysis of professional athletes Tweets and follower engagement (Hambrick, et 
al., 2010), a case study investigating the impact of the linguistic patterns and language expressions among major brands (Jansen, et al., 2009), a comparative analysis of the interactivity of tweets sent by American and Australian organizations (Burton \& Sobleva, 2011), perceptions of the organization-public relationship based on levels of interactivity (Saffer, et al., 2013) and use of Twitter as an interactive tool by luxury fashion brands (Goode, 2013).

This emerging body of research indicates that the level of interactivity and language of comments play a role in online engagement, as well as users feelings about the relationship with the spokesperson or organization. To date, however, this research has yet to explore varying source types' perceived credibility and the impact this has on Twitter followers' intention to interact with the message online. Thus, this study seeks to explore this relationship.

Given that one aim of this study is to assess the interactivity intention of a Twitter user, based on source type (rather than the content of the message), the author will focus on interpersonal activity. Thus, interactivity is defined as the likelihood of a Twitter user to comment, favorite or share a message on Twitter. As there is no research focused on the source of a fashion message and Twitter followers intention to interact with the message, how the audience will make the decisions about interactivity of this message remains questionable. Thus the following research question is asked.

RQ2: Is there a relationship between the source type of a fashion industry Twitter message and interactions on Twitter?

\subsection{Purchase Intention}

As the ultimate goal of marketing and advertising efforts is to get consumers to purchase 
products, this study also seeks to better understand purchase intention based on the source of fashion industry Twitter messages. As posited in the theory of planned behavior, intention indicates an individual's readiness to perform a behavior and serves as an antecedent to actual behavior (Ajzen, 2002). In marketing research, purchase intention is important because it helps to achieve a behavioral understanding of consumers, as it serves as a predictor of purchase behavior (Morwitz \& Schmittlein, 1992). In fact, purchase intention is the key index used in predicting consumer behavior (Armstrong \& Kotler, 2003).

\section{Purchase Intention Defined}

As Kim et al., (2010) have indicated, forecasting of consumers' future behavior is an increasingly critical issue. Schiffman and Kanuk (2000) define purchase intention as a transaction behavior that consumers tend to perform after evaluating a product; or the purchase likelihood based on the consumer's reaction to a product. In a marketing context, purchase intention is a combination of consumers' interest in and possibility of buying a product based on promotional messages received.

Numerous studies have found that purchase intention is strongly related to attitude and preference toward a brand or a product (e.g., Kim, Kim \& Johnson, 2010; Kim \& Ko, 2010a; Kim \& lee, 2009, Lloyd \& Luk, 2010). In the context of social media based fashion promotions, it is presumed that the cognitive processes associated with purchase decision occur prior to the actual purchase, therefore these online marketers must know how to influence potential customers in their pre-purchase stage. To test this presumption, this study seeks to assess if attitudes, in terms of perceptions of source credibility, are related to purchase intention. 
Previous research on the topic has primarily focused on the relationship of different dimensions of source credibility and purchase intentions. For example, Ohanian (1990) found that only expertise of source credibility is a significant factor explaining the respondents' intentions to purchase; while Kahle and Homers' research (1985) indicates that the persuasive power of endorser increases if he or she is attractive. Given these potentially conflicting findings, the author elected to consider overall source credibility of varying source types, (rather than investigating incremental dimensions) in an effort to assess the relationship of the message source on purchase intention.

\section{Source Credibility and Purchase Intention}

Previous research has found that when recipients of a message understand and feel positively toward an endorsement message there is also a positive influence on purchase intention (Lafferty \& Goldsmith, 1999). With reference to the brand, Robertson and Gatignon (1986) found that consumer's knowledge of a brand reduces uncertainty when making purchase decisions, leading to a preference to buy products from brands with better images. Additionally, although Rice and Trout (1986) warn that celebrity endorsement selection by companies should be carefully considered to assure increased consumer purchase intention, Wang, Cheng and Chu (2013) found that when brands combine celebrities and products there are positive consumer-based effects.

Similarly, scholars have also begun to explore the effects of social media marketing on behavioral intention. For instance, in a study of the effects of tweets on movie sales, findings indicate that more positive tweets about a movie was associated with increased movie sales (Rui, 
Lie \& Whinston, 2011). In a study of the micro-blog webpages of corporations in Taiwan, Hsu, Liu and Lee (2010) employed a relationship marketing perspective and found that consumers' satisfaction was influential in behavioral intention. In the fashion industry, purchase intention based on social media marketing for luxury fashions has been shown to relate to purchase intention (Kim \& Ko, 2010b; Kim \& Ko, 2012). However, in a study of brand marketing on Facebook, social media communication from a brand did not influence consumer purchase intention of the brand (Schvinski \& Dabrowski, 2013).

What these studies do not shed light on is differences between purchase intentions based on spokespersons' (brand, celebrity, friend/acquaintance) messages on social media. In order to explore the relationship between the source types and potential customers' purchase intentions, a final research question is posed.

RQ3: Is there a relationship between the source of a fashion industry Twitter message and purchase intention? 


\section{Chapter 3: Methodology}

This overall aim of this research is to examine perceptions of fashion-industry Twitter message sources and the effects different source types have on desirable behavioral outcomes. To accomplish this, the research has three objectives. First, the author seeks to determine if different sources of fashion industry Twitter messages (celebrities, brands, friends/acquaintances) are perceived as more credible. Next the author will assess if these different sources are likely to garner different levels of online engagement with reference to their Twitter-based fashion messages. Finally, the other will explore if different Twitter messengers are likely to increase levels of purchase intention of fashion merchandise.

\subsection{Survey}

Given that Wrench et al (2008, p. 213) have indicated that surveys are "a social scientific method for gathering quantifiable information about a specific group of people by asking group members questions about their individual attitudes, values, behaviors, knowledge, and perceptions," this methodology will be applied in the context of this study. Surveys are an appropriate methodology because they allow researchers to examine their variables of interest at a low cost and provide the opportunity to reach a large population with different demographic backgrounds. Surveys are also relatively easy to administer and can be developed in less time compared to other data-collection methods (Sincero, 2012). Further, compared to other methodology such as experiments, surveys do not need specific stimuli such as particular brand, celebrity endorser or friend. This means that respondents are able to reflect on their reactions to their preferred brand, rather than one provided by the researcher, thus increasing the 
generalizability of findings.

Using online surveys tends to be the most cost-effective modes of survey research, (Keyton, 2006) and therefore the author will distribute the questionnaire via the Internet. This modality allows for remote distribution and reduces geographical dependence (Wyse, 2012). Thus an online questionnaire will be launched for this research to collect responses from participants.

\subsection{Survey Measures}

This study has one independent variable and three dependent variables. The independent variable of sources of fashion industry Twitter message, are formal opinion leaders and informal opinion leaders. Formal opinion leaders include celebrity endorsers on Twitter and brands' official Twitter accounts. Informal Opinion leaders refer to friends or relatives on Twitter. The dependent variables of this research are perceived source credibility of the fashion-industry message, audiences' interactivity and purchase intention.

\section{Source Credibility}

According to DeSarbo and Harshman (1985), there are three constructs of credibility: expertise, trustworthiness, and attractiveness, while McCroskey (1966) holds that character is also a very important construct. Kang has advanced a model to measure blogger source credibility in terms of effectiveness, which will be used in this study. Thus in this research, five dimensions of the dependent variable of credibility were measured. To measure attitudes towards source credibility, semantic differential scales with a five-point range between bi-polar adjectives were employed.

The measurement scale used for trustworthiness, expertise, and attractiveness is from 
Ohanian research (1989). Expertise was measured with adjectives of "expert," "experienced," "knowledgeable," "qualified" and "skilled;" trustworthiness was measured as “dependable," "reliable," "trustworthy," "honest" and "sincere," and attractiveness was measured as "attractive," "classy," "beautiful," "elegant" and "sexy." For the measurement of character, the McCroskey (1966) scale was applied and was measured using the adjectives "honest," "friendly," "pleasant" and "virtuous." Kang's original scale included five items to measure effectiveness. Given overlap with other variables, only three items were retained: "influential," "passion," "transparent."

\section{Interactivity}

There is a lack of consensus on how to precisely conceptualize interactivity, as it applies to social media differently due to different attributes and functions of websites (Lilleker, \& Malagon, 2010). In order to measure the respondents' intention to interact with a message from a particular source, therefore a comprehensive list of possible interactions on Twitter needed to be created. Thus, the author searched technology blogs to analyze all possible interaction options provided by Twitter. According to Ryan (2011), the main methods of interactions on Twitter are "tweet," "reply," "reTweet," "favorite," and "follow." But upon reviewing the Twitter Glossary (2014), more interaction types were identified, including "direct message," "modified Tweet" and "share outside of Twitter." Combining these interaction types provided the measurement of the respondents possible interactivity. For each source, respondents were asked how likely they would be to perform these interaction on a 5-point Likert-type scale ranging from "very unlikely" to "very likely." 


\section{Purchase Intention}

Research has identified many factors that influence consumers' purchase intentions. Some of the key factors include compatibility and usefulness (Yulihasri et al., 2011), as well as product variation, product quality, product design, brand name and packaging (Karbala and Wanderbori, 2012). Further, Vigneron and Johnson (1999) found that luxury fashion purchase intentions are motivated by three main dimensions: to signal enhanced status through a display of goods with perceived great value; to show the uniqueness and exclusivity; and to symbolize group membership as indicated under the influence of conformity.

This body of research informed the development of seven items to measure purchase intention. The items included in the questionnaire inquire about the increased likelihood of purchase if the product is "reasonably priced," "easy to buy online," "appears to be a great value," "compliments the personal style of the respondent" or if "it looks like something the respondent's friend group might wear." Respondents were also asked if they might be more inclined to "purchase the product in a store later," and if their likelihood of purchase was increased by "need for an outfit for an upcoming occasion." For each item, responses were measured on a 5-point Likert-type scale ranging from "very unlikely" to "very likely."

Previous research has also indicated that demographic differences are important factors influencing consumers' purchase intentions (Karbala, \& Wanderbori, 2012). Therefore, the author also included demographic questions related to gender, age, employment, education and income. Further, given the social media based focus of the study, the questionnaire included queries about social media use including preferred platform, time spent on social media on an 
average day and estimated number of followers on Twitter. The full questionnaire can be found in Appendix D.

\subsection{Sample}

As the fashion industry has been said to engage all social classes and function across socio-economic status, it was important to have a diverse sample. In order to collect data from a nationally-based respondent pool, the web-based micro-platform Amazon Mechanical Turk (MTurk) was used. MTurk is an online labor system run by Amazon that allows people to finish work or answer "Human Intelligence Tasks" (HITs) in exchange for money (Goodman et al, 2013). According to Rand (2011), MTurk demographic responses are more diverse than standard internet samples, making this an ideal population for this study of fashion industry Twitter

messages. Further, research has found that data collected through MTurk is at least as reliable as data collected through traditional methods (Behrend, T., Sharek, D., Meade, A., \& Wiebe, E., 2011), making it more desirable to the author than a student or other similar nonprobability samples. Using the MTurk interface 400 workers were requested. Each participant received $\$ 0.20$ for fully completing the online survey.

\subsection{Analysis Process}

As the online questionnaire was launched on MTurk, the data were collected in this system and then downloaded to analyze in SPSS. All procedures outlined in the current work received approval from the university's institutional review board (IRB). Appendix 2 contains the approval letter from the IRB.

Prior to analyses, all data were cleaned and incomplete cases removed. To assess questions 
and hypotheses associated with credibility of source type, summated scales for each of the dimensions of credibility were created (e.g. expertise, character, attractiveness). To form a composite scale for overall credibility one item from each dimension was used to form a summated scale. In the case where there was a parallel adjective (e.g. the "attractive" adjective for the attractiveness dimension) this indicator was used. In instances when no parallel adjective existed, the item with the highest mean was used for that dimension. To address questions associated with interactivity and purchase intention, findings look at individual indicators associated with each behavioral outcome. Overall summated scales for interactivity and purchase intention were also created. Cronbach's alpha was used to assess reliability of all the scales used in this study.

To test the first three hypotheses and answer the first research question, descriptive statistics were used. Namely, frequencies were used to determine how each source was evaluated on the five dimensions of credibility, as well as the overall credibility factor (H1-3). Means were then used to assess which source was perceived as the most credible overall (RQ1). To test the remaining research questions associated with interactivity and purchase intention, descriptive statistics were used to analyze likelihood of online engagement and purchase. Then, to test if there is a relationship between credibility and interactivity or intention, Pearson's R was used. This statistical test allows testing for significant correlations. See Figure 1 for a complete list of hypotheses, research questions and associated statistical tests. 
Figure 1

Research Questions, Hypotheses and Associated Statistics Tests

\begin{tabular}{|c|c|}
\hline Hypotheses and Research Questions & Statistics Test \\
\hline H1: Official messages from the brand or designer will be viewed as credible & Descriptive \\
\hline sources of fashion messages on Twitter. & statistics \\
\hline H2: Celebrity endorsers will be viewed as credible sources of fashion & Descriptive \\
\hline messages on Twitter. & statistics \\
\hline H3: Informal opinion leaders (e.g. friends/acquaintances) viewed as credible & Descriptive \\
\hline sources of fashion messages on Twitter. & statistics \\
\hline $\begin{array}{l}\text { RQ1: What source (official brand/designer, celebrity endorser, informal } \\
\text { opinion leader) will be viewed as the most credible source of fashion }\end{array}$ & $\begin{array}{l}\text { Descriptive } \\
\text { statistics }\end{array}$ \\
\hline \multicolumn{2}{|l|}{ messages on Twitter? } \\
\hline RQ2: Is there a relationship between the source type of a fashion industry & Descriptive \\
\hline \multirow[t]{2}{*}{ Twitter message and interactions on Twitter? } & statistics and \\
\hline & Pearson's R \\
\hline RQ3: Is there a relationship between the source of a fashion industry Twitter & Descriptive \\
\hline message and purchase intention? & statistics and \\
\hline & Pearson's R \\
\hline
\end{tabular}




\section{Chapter 4: Results}

The purpose of this study is three-fold. First, the author seeks to understand perceived credibility of different source types (brand, celebrity, friend/acquaintance) for Twitter messages related to fashion. Next the author seeks to better understand the relationship between these source types and interactivity with the Twitter message. Finally, this study explored the relationship between the different source types and behavioral intention associated with purchase. This chapter focuses on findings associated with the aforementioned hypotheses and questions.

Before launching the survey, a pretest was conducted. The full questionnaire was sent to a sample of 60 participants ranging in demographics and proficiency with Twitter. Of those asked to participate, 33 completed the full instrument. After reviewing responses, the survey was deemed ready to launch. Using the MTurk interface 400 workers were requested. Each participant received $\$ 0.20$ for fully completing the online survey. At the end of the first week of data collection, there were 413 responses. Sixty-three incomplete cases had to be removed, resulting in 350 useable responses. These responses were combined with the 33 complete responses from the pre-test and data analysis proceeded with a sample of 383 individuals who indicated they use the micro-blogging platform Twitter, and have an interest in fashion.

Among the 383 respondents who completed the questionnaire, $60 \%(\mathrm{n}=230)$ were males and $39 \%(n=151)$ were females. Approximately $44 \%(n=167)$ of respondents were between the ages of 26 and 35 , followed by the 18 to 25 age group $(43 \%, n=166)$. In terms of education, the majority of respondents reported having a bachelor's degree or higher $(77 \%, \mathrm{n}=292)$, Nearly half 
of the respondents indicated they were employed full time $(47 \%, \mathrm{n}=181)$, another $17 \%(\mathrm{n}=64)$ indicated part-time employment and $6 \%(\mathrm{n}=21)$ were unemployed. Among the 380 respondents who provided information on their estimated household income for the current year, nearly half reported household income of under $\$ 25,000(43 \%, n=163)$. Other frequently identified ranges included $24 \%(\mathrm{n}=91)$ at $\$ 25,000$ to $\$ 39,999$ and $14 \%(\mathrm{n}=52)$ at $\$ 40,000$ to $\$ 49,999$.

When asked the social media platform most often used, 51\% $(\mathrm{n}=194)$ chose Facebook, while $38 \%(\mathrm{n}=146)$ chose Twitter, followed by YouTube $(7 \%, \mathrm{n}=26)$ and Instagram $(3 \%, \mathrm{n}=11)$. Approximately half of the respondents spent one to three hours on social media networks everyday $(48 \%, \mathrm{n}=184)$, followed by less than one hour $(27 \%, \mathrm{n}=103)$, three to six hours $(16 \%$, $\mathrm{n}=63)$, and more than 6 hours $(8 \%, \mathrm{n}=29)$. Among the 382 respondents who answered the question about the number of followers they had on Twitter, half replied they had between 101 and 500 followers $(51 \%, \mathrm{n}=194), 35 \%(\mathrm{n}=132)$ reported between 501 and 1000 followers, $9 \%$ $(\mathrm{n}=36)$ reported more than 1000 followers, and 2\% $(\mathrm{n}=9)$ reported less than 100.

When asked about their reason for purchasing fashion items, half of the respondents reported that the reason they were most likely to buy was "as a form of self expression" $(50 \%, n=192)$. Approximately a third of the respondents indicated that they bought fashion items "to fit in with my friends" (31\%, n=119). To a lesser degree respondents indicated that, "I only buy fashion apparel for special occasions" $(11 \%, \mathrm{n}=41)$.

In order to explore the three hypotheses and the first research question, a series of questions that tested the perceived credibility of the three source types (celebrity, brand, friend/acquaintance) were asked. When asked directly which source respondents perceived to be 
the most credible, $45 \%(\mathrm{n}=173)$ respondents regarded the brand's official account as the most credible Twitter source, $32 \%(n=123)$ indicated celebrity endorsers were most credible and 22\% $(n=85)$ indicated friends or relatives as the most credible source. When asked the Twitter source they were most likely to turn to for information, $38 \%(n=146)$ reported the brand's official account, $31 \%(n=119)$ reported friends or relatives, while $30 \%(n=114)$ reported celebrity endorsers.

To further explore perceptions of source credibility, respondents were also asked to react to a series of bi-polar adjectives while considering different source types in turn. The items were intended to explore dimensions of credibility including expertise, character, attractiveness, trustworthiness and effectiveness. Summated scales were created for each dimension, and an overall credibility scale was created from parallel adjectives or the indicators with the highest mean in each dimension.

As seen in Table 1 all three sources are perceived as credible sources of fashion information on Twitter. Thus, H1, H2 and $\mathbf{H 3}$ positing that the three sources will be seen as credible sources, were supported. To more fully understand the dimensions of credibility, the author also reports in Table 1 mean scores for all dimensions of credibility for each source type. Findings indicate that brand as a Twitter source of fashion information, scored the highest on the dimensions of expertise $(M=4.05, S D=.75)$, attractiveness $(M=3.98, S D=.75)$ and effectiveness $(M=3.98$, $\mathrm{SD}=.79)$ However, friends were perceived to be more credible when it comes to dimension of character $(\mathrm{M}=3.99, \mathrm{SD}=.78)$ and trustworthiness $(\mathrm{M}=4.06, \mathrm{SD}=.78)$. Interestingly, the lowest credibility score related to the trustworthiness $(\mathrm{M}=3.75, \mathrm{SD}=.83)$ of celebrity as source type. 
With reference RQ1, brand as source type was perceived to be the most credible as it relates to fashion messages on Twitter $(\mathrm{M}=4.02, \mathrm{SD}=.79)$.

Table 1

Means, Standard Deviations and Reliability Coefficients for Credibility by Source Type

Score

Brand

Expertise

Character

Attractiveness

Trustworthiness

Effectiveness

Overall Credibility

Friend/Acquaintance

Expertise

Character

Attractiveness

Trustworthiness

Effectiveness

Overall Credibility

\section{Celebrity}

Expertise

3.90

.83

.87

Character

3.78

.83

.83

Attractiveness

3.96

.79

.84

Trustworthiness

3.75

.83

.86

Effectiveness

3.85

.79

.65

Overall Credibility

3.89

.76

.91

Note. Scores are on a scale of 1 to 5 from "strongly disagree" to "strongly agree." $n=383$.

To explore RQ2 related to the relationship between interactivity and source credibility, respondents were asked to indicate how likely they would be to take online action related to Twitter messages from different source types. Findings indicate that respondents were only 
somewhat likely to actively engage online with the varying source types. In fact, most items approached the mid-point of the scale, indicating neutrality. The highest overall interactivity score related to the respondents" likelihood to "search online" for additional information related to a Twitter post from a brand's official account ( $\mathrm{M}=4.02, \mathrm{SD}=.91)$, or "follow" the brand's official page ( $\mathrm{M}=3.85, \mathrm{SD}=.98)$. Respondents also indicated they were more likely to "favorite" a message from a brand $(\mathrm{M}=3.77, \mathrm{SD}=1.04)$ or friend $(\mathrm{M}=3.72, \mathrm{SD}=1.04)$, rather than taking most other actions related to interactivity. On nearly every interactivity indicator, celebrity as source type scored the lowest.

To assess the overall likelihood of interactivity with each source type, summated scales for all interactivity indicators were created. Reliability for brand, friend and celebrity all exceeded $\alpha$ $=.80$. When considering overall likelihood of interactivity, respondents were most likely to be interactive with the brand $(\mathrm{M}=3.64, \mathrm{SD}=.79, \alpha=.87)$, followed by a friend $(\mathrm{M}=3.62, \mathrm{SD}=.81$, $\alpha=.89)$, and finally celebrity ( $\mathrm{M}=3.45 . \mathrm{SD}=.89, \alpha=.90)$. Means for each of the interactivity indicators, as well as the overall interactivity score are reported in Table 2. 
Table 2

Mean Scores for Interactivity by Source Type

\begin{tabular}{lccc} 
Interactivity & \multicolumn{3}{c}{ Source Type } \\
\cline { 2 - 4 } Follow & Brand & Friend & Celebrity \\
\cline { 2 - 4 } Reply & $3.85(.98)$ & $3.60(1.04)$ & $3.61(1.09)$ \\
ReTweet & $3.50(1.18)$ & $3.66(1.04)$ & $3.32(1.18)$ \\
Favorite & $3.63(1.09)$ & $3.69(1.07)$ & $3.45(1.12)$ \\
Direct message & $3.77(1.04)$ & $3.72(1.04)$ & $3.59(1.11)$ \\
Modified tweet & $3.51(1.18)$ & $3.57(1.14)$ & $3.28(1.26)$ \\
Share outside of & $3.43(1.17)$ & $3.44(1.14)$ & $3.33(1.19)$ \\
Twitter & $3.44(1.16)$ & $3.43(1.18)$ & $3.30(1.21)$ \\
Search online & $4.02(.91)$ & $3.88(1.01)$ & $3.72(1.03)$ \\
\hline Overall Interactivity & $3.64(.79)$ & $3.62(.81)$ & $3.45(.89)$ \\
\hline
\end{tabular}

Note. Scores are on a scale of 1 to 5 from "Very unlikely" to "Very likely." Standard deviations in parentheses. $n=383$.

To further explore RQ2, the author also explored the linear relationship for the likelihood of interactivity with a fashion-focused Twitter post based on perceived source credibility. Findings indicate a significant positive correlation between all source types and interactivity level. This means interactivity increases when the brand $(r=.44, \mathrm{n}=383, \mathrm{p}=.00)$, friend $(\mathrm{r}=.47, \mathrm{n}=383, \mathrm{p}=.00)$ and celebrity $(\mathrm{r}=.44, \mathrm{n}=383, \mathrm{p}=.00)$ are perceived as credible sources of fashion information.

The author next investigated purchase intention based on Twitter messages from different 
source types (RQ3). As seen in Table 3, brand was the source that was most likely to evoke respondents' purchase intention based on a Twitter message $(\mathrm{M}=3.89, \mathrm{SD}=.70)$. While all of the indicators associated with purchase intention were somewhat important, messages from a brand were more likely to garner purchase intention if the respondent perceived the focus of the fashion post to be affordable $(\mathrm{M}=3.96, \mathrm{SD}=.94)$, a good value $(\mathrm{M}=3.98, \mathrm{SD}=.91)$ and complimenting personal style $(\mathrm{M}=3.96, \mathrm{SD}=.96)$.

As a final exploration of RQ3, the author analyzed the linear relationship between source credibility and purchase intention. Findings, once again, indicate that greater perceived credibility increases the likelihood of behavioral outcomes. More specifically, purchase intention increases based on a fashion industry Twitter message, if the brand $(r=.56, n=383, p=.00)$, friend $(\mathrm{r}=.57, \mathrm{n}=383, \mathrm{p}=.00)$ and celebrity $(\mathrm{r}=.58, \mathrm{n}=383, \mathrm{p}=.00)$ were perceived to be credible. 
Table 3

Mean Scores for Purchase Intention by Source Type

\begin{tabular}{llll} 
& \multicolumn{3}{c}{ Source Type } \\
\cline { 2 - 4 } & Brand & Friend & Celebrity \\
\cline { 2 - 4 } Affordable & $3.96(.94)$ & $3.86(.99)$ & $3.86(.97)$ \\
Easy to buy online at the moment & $3.82(.99)$ & $3.72(1.00)$ & $3.64(1.02)$ \\
Easy to buy later at a store or online & $3.80(.93)$ & $3.74(.96)$ & $3.74(.95)$ \\
In need of a new outfit for event or occasion & $3.89(.96)$ & $3.87(.91)$ & $3.75(1.01)$ \\
Appears to be of great value & $3.98(.91)$ & $3.89(.95)$ & $3.89(.97)$ \\
Complements personal sense of style & $3.96(.96)$ & $3.88(.96)$ & $3.91(.99)$ \\
Looks like something that my group of & $3.81(.95)$ & $3.81(.96)$ & $3.74(1.00)$ \\
friends or I might normally wear & & & $3.79(.74)$ \\
\hline
\end{tabular}

Note. Scores are on a scale of 1 to 5 from "Very unlikely" to "Very likely." Standard deviations in parentheses. $n=383$. 


\section{Chapter 5: Discussion}

The purpose of this study was to investigate the perceptions of credibility, as well as likelihood of interactivity and purchase intention based on different source types of a fashion industry Twitter message. To explore these questions, the study first investigated measures assessing perceived source credibility. Then interactivity and purchase intention were explored by testing the relationship between source type, as well as the perceived credibility of the source. This chapter first discusses implications from the results that may provide some insight for brands and designers. The author then reviews limitations of the study. Finally the author concludes with the main findings of this study and puts forward suggestions for further research that focuses on source credibility of social media posts and fashion industry online marketing.

\subsection{Findings and Implications}

This study offers many insights into the perceived credibility, interactivity and purchase intention of consumers based on Twitter-based fashion messages from different sources. First, celebrity endorsers were perceived as the least credible, and also scored the lowest in evoking respondents' online engagement and purchase intentions. These results are in accordance with a recent Nielsen report (2012) that found individuals buy things not because a celebrity tells them to, but because of their family and friends recommendations. These findings are important for

social media planners in the fashion industry looking to assure a return on investment. Compared to other types of Internet advertising, online celebrity endorsements are often more expensive. For example, according to Piazza (2012), Kim Kardashian was paid \$10,000 for a Twitter endorsement, while Snoop Dog received \$8,000. Collectively, these findings indicate that 
fashion brands may wish to reconsider the use of celebrity endorsers in the context of Twitter.

From an online engagement standpoint, respondents in this study were more likely to simply follow a Twitter account, or favorite a post, rather than more active engagement such as reTweet, reply and modified tweet. From a measurement standpoint, this is important. While concepts like crowd sourcing and two-way online communication may be the desired outcome, results from this study indicate that they are not as likely as more passive forms of engagement. It is unclear, however, what factors motivate more active engagement, such as sharing information with their own followers and responding to posts from the source. The relationship between varying forms of active engagement and conversion to purchase is also unclear. It is possible that tweets actually serve as a form of advertisement, like a billboard, rather than a forum that discusses and encourage viral sharing of fashion trends. Future research is needed to better understand this phenomenon.

Further, fashion brands should be encouraged by findings from this study indicating a relatively high probability of tweets from their official page evoking intention to search for additional information online. It is probable that a person who is seeking additional information (e.g., price, styles, sizes) is doing so in order to make a purchase decision. Further, on their official Twitter page, the brand or designer have the ability to control the message in a way that they could not if the information was posted by another source. Thus, social media strategists should focus attention and resources on managing and operating their official Twitter accounts as a fiscally responsible communication strategy. Additionally, providing easy access to additional information (e.g., hyperlinks) improves the follower's ease of access and the brands control of 
the flow of information.

Findings from this study also inform our understanding of purchase intention based on varying sources of Twitter-based fashion posts. First, purchase intentions based on posts from the official brand account were higher than any other source. Second, respondents' likelihood towards purchase intention was higher when respondents perceived affordability, value and ability to compliment their personal style. Thus, in terms of messaging and voice, social media strategists in the context of the fashion industry, may find it more productive to provide pricing information and carefully consider their audiences' style preferences when promoting products, trends and designers.

Finally, findings from this study indicate that, among all source types, both interactivity and purchase intention increase if credibility increases. Therefore, maintaining source credibility is of great significance to those brands that want to engage followers on Twitter and to increase sales. This indicates that when Kenneth Cole insensitively latched onto the trending \#Cairo hashtag to promote their spring line in 2011, or in 2013 when they seemingly made light of the crisis in Syria while promoting their footwear, they may have damaged more than their days Twitter analytics; they may have affected their long-term bottom line. This also indicates that considering the source alone is not enough. The Twitter message content may also affect certain dimensions of credibility. For example, from the standpoint of the Kenneth Cole social media crisis, it may be that the negative backlash from followers resulted from negative perceptions of character. Rather than impacting perceptions of other dimensions (e.g., attractiveness), it is possible that the source's inappropriate use of trending war-related hashtags, led followers to 
regard the brand as unfriendly, unpleasant, awful or not virtuous. More directly stated, it is imperative that fashion brands manage their Twitter accounts professionally to assure their content is perceived as expert, friendly, attractive, trustworthy and passionate. Further, that the content of the message is considered across the multiple dimensions of credibility explored in this study.

\subsection{Limitations}

As with all research, this study has limitations. The first concern is regarding the sample of the study. According to the demographic information provided by respondents, nearly half of them reported an annual household income under $\$ 25,000$. Thus, it is possible that high-end fashion consumers, who conceivably might have a higher household income, were missing from the results of the study. Further, as the survey was published as a HIT on MTurk with a reward of $\$ .20$ for every completed response, it is not possible to discern participant motivation. It is possible that some participants were incentivized by the reward, and did not answer the questions seriously.

Another limitation of the study is based on the length of the survey. There were three different source types in this survey, therefore the same question block were repeated three times. This added to the length of the survey, which might cause some participants to lose patience and quit before completion. When cleaning the incomplete data, the author found that most incomplete responses stopped at the spot where the questions of the second source type started. At the end of data collection, the author had 473 responses including the pretest, but there were only 383 complete ones, resulting in a completion rate of $81 \%$. 
Additionally, this study is focused on Twitter-based fashion industry messages and respondents preferred brand, respected friend and revered celebrity. As such, these findings may not be generalizable to other marketing contexts, industries or social media platforms. Further, findings may not be generalizable across brands, as respondents were preconditioned to consider a brand that they already thought positively about.

\subsection{Future Research}

Findings from this study, however, provide a foundation for future research. Though this study is limited in the fashion industry, it provides a template for future researches that wish to investigate credibility of other social media messages in other industries. Repeating this study in other communications' contexts may shed light on the relationship between source and credibility, as well as how these factors relate to interactivity and purchase intention.

Additionally, our understanding of the effectiveness of varying sources in Twitter-based marketing would be enhanced by employing other methodologies to investigate perceived source credibility, online engagement and behavioral intention. For example, experiments with different messaging strategies and specific reference to message source could provide nuanced understanding of the relationship between variables. Ethnographic research investigating consumers' actual purchase behavior and interactivity could also add to our understanding of temporal order. Qualitative research, such as focus groups and in-depth interviews, may also provide a more thorough understanding of other variables that point to attitudes, behaviors and motivations. Last but not least, surveys or other methodologies, may be effectively employed to inquire about sources with varying levels of popularity and respect to ascertain if the results from 
this study are replicable across varying messengers. 


\section{Chapter 6: Conclusions}

Employing a web-based survey $(\mathrm{n}=383)$, this research explored the relationship between source credibility, interactivity and purchase intentions in the context of fashion industry marketing, based on varying sources of Twitter messages. Findings indicate that all source types (brands, friends, celebrities) were perceived to be credible by respondents. Among the three types, however, brand scored highest across measures of source credibility, interactivity and purchase intention. Conversely, celebrity endorsers who are typically paid large sums of money for online endorsements, scored lowest in all of the three variables. When it comes to friends and acquaintances as a message source, findings indicate that in terms of dimensions of credibility, they were most trusted. Thus, brands may need to reconsider and reevaluate the effectiveness of social media celebrity endorsements on Twitter.

Findings also revealed interesting insights associated with online engagement and purchase intention, First, respondents were more likely to search for more information online based on a Twitter post from a brand over any other interactivity measure. Second, respondents tended to purchase products when they were perceived to be affordable, of high value or could complement an individual's personal style. Third, when credibility is perceived to be high, interactivity and purchase intention increase. These findings inform social media strategies associated with messaging. Providing hyperlinks, credible content and information associated value and style, will improve the effectiveness of communication.

Finally, findings revealed insight into measurement of effective Twitter-based campaigns in the fashion industry. The online interactivity that respondents were most likely to engage in was 
to follow a source or favorite a post. Respondents were less likely to engage in viral word of mouth activities like reTweet, comment or post a modified tweet. Thus, while the potential to develop a relationship with consumers online remains viable, setting campaign objectives and the metrics to measure effectiveness of social media strategies needs to be carefully considered with these findings in mind. 


\section{References}

Achiilladelis, B., Jervis P., \& Robertson A. (1971). A study of success and failure in industrial innovation. Sussexx, England: University of Sussex Press.

Ajzen, I. (2002). Perceived Behavioral Control, Self-Efficacy, Locus of Control, and the Theory of Planned Behavior. Journal of Applied Social Psychology, 32, 665-683.

Allen, K. (2013). The Top 50 Fashion Brands on Social Media. Ragan's PR Daily. Retrieved from http://www.prdaily.com/Main/Articles/The_top_50_fashion_brands_on_social_media_13 564.aspx\#.

Armstrong, G., \& Kotler, P. (2003). Marketing: An introduction. Upper Saddle River, NJ: Prentice Hall.

Arndt, J. (1967). Role of product-related conversations in the diffusion of a new product. Journal of Marketing Research, 4(3), 291-295.

Baar, A. (2013). Nielsen: consumers trust WOM over other messaging. Retrieved from http://www.mediapost.com/publications/article/209286/nielsen-consumers-trust-wom-ov er-other-messaging.html.

Baker, M., \& Churchill, G. (1977). The impact of physically attractive models on advertising evaluations. Journal of Marketing Research. 14(11), 538-555.

Batra, R., \& Homer, P. (2004). The situational impact of brand image belief. Journal of Consumer Psychology. 14(3), 318-330.

Beacham, F. (1995). Questioning technology: tools for the revolution. Media Culture Review. 
4(6), 18.

Behrend, T., Sharek, D., Meade, A., \& Wiebe, E. (2011). The viability of crowdsourcing for survey research. Behavior Research Methods, 43(3), 800-813.

Bennett, S. (2014). The top 10 fashion brands on twitter [STATS]. Retrieved from https://www.mediabistro.com/alltwitter/top-10-fashion-brands b54948.

Bourieu, P. (1979). La distincation. Paris: Ed. Minuit.

Brand, S. (1987). The media lab: Inventing the future at MIT. New York, NY: Viking Penguin.

Brown, L. (n.d.). Study: How many people follow brands on social media. WTWH Media Marketing Lab. Retrieved from http://marketing.wtwhmedia.com/study-how-many-people-follow-brands-on-social-medi a-and-why.

Burton, S., \& Soboleva, A. (2011). Interactive or reactive? Marketing with Twitter. The Journal of Consumer Marketing. 11(28), 491-499.

Busby, E., Field, D., Forth, P., Harsaae, J., Rose, J., \& Salha, H. (2010). The CMO’s imperative: tracking new digital realities. Retrieved from www.bcg.com/documents/file66995.pdf.

Carroll, A. (2005). Who's that Girl? Celebrity Endorsement Revisited. Proceedings of Academy of Marketing Conference, 5-7 July, Dublin: Dublin Institute of Technology.

Carroll, A. (2009). Brand communications in fashion categories using celebrity endorsement. Journal of Brand Management, 17, 146-158.

Chaiken, S. (1979). Communicator physical attractiveness and persuasion. Journal of Personality 
and Social Psychology, 37(2), 1387-97.

Chakrabarti, A.K. (1974). The role of champion in production innovation. California Management Review, 17, 58-62.

DEI Worldwide. (2008). The impact of social media on purchasing behavior: Engaging consumers online. Retrieved from www.deiworldwide.com/files/DEIStudy-Engaging\%20ConsumersOnline-Summary.pdf

DeSarbo, W.S., \& Harshman, R. (1985). Celebrity-brand congruence analysis. Current Issues and Research in Advertising. Division of Research, Graduate School of Business Administration, The University of Michigan, 17-52.

Dion, K, \& Berscheid, W.E. (1972). What is beautiful is good. Journal of Personality and Social Psychology, 24(4), 285-90.

Duggan, M., \& Smith, A. (2013). Social Media Update 2013. Pew Research Internet Project. Retrieved from http://www.pewinternet.org/2013/12/30/social-media-update-2013/.

Engel, J.F., Blackwell, R.D., \& Miniard, P.W. (1995). Consumer Behavior, $8^{\text {th }}$ ed. London: Dryden Press.

Flanagin, A.J., \& Metzger, M.J. (2000). Perceptions of internet information credibility. Journalism and Mass Communication Quarterly, 77(3), 515-540.

Giffin, K. (1972). The contribution of studies of source credibility to a theory of interpersonal trust in the communication process. Psychological Bulletin, 68, 104-19.

Gladwell, M. (2000). The tipping point. Little, New York, NY: Brown and Company. Goode, A. (2013). Twitter and fashion: A quantitative investigation of the use of Twitter as an 
interactive tool by luxury fashion brands. Retrieved from

https://digital.library.txstate.edu/handle/10877/4541.

Goodman, J., Cryder, C., \& Cheema, A. (2013). Data collection in a flat world: the strengths and weaknessf Mechanical Turk samples. Journal of Behavioral Decision Making, 26, 213-224.

Guillory, J., \& Sundar, S.S. (2008). Can interactivity in corporate websites influence public perceptions of organizations? Proceedings from International Communication Association Conference. Montreal, Canada.

Hambrick, M. E., Simmons, J. M., Greenhalgh, G. P., \& Greenwell, T. C. (2010). Understanding Professional Athletes' Use of Twitter: A Content Analysis of Athlete Tweets. International Journal of Sport Communication, 3(4).

Helmore, E. (2010, November 15). Google targets fashion market. Retrieved from http://www.theguardian.com/technology/2010/nov/15/google-targets-fashion-market-bou tique.

Hiray, J. (2007, June 6). Formal and informal leader. Retrieved from http://businessmanagement.wordpress.com/2007/06/06/formal-and-informal-leader/.

Hoffman, D., \& Novak, T. (1996). Marketing in hypermedia computer-mediated environments: conceptual foundations. Journal of Marketing, 60(3), 50-68.

Hovland, C.I., Janis, I.L., \& Kelley, H. (1953). Communication and persuasion. New Haven, CT: Yale University Press.

Hsu, C. L., Liu, C. C., \& Lee, Y. D. (2010). Effect of Commitment and Trust towards 
micro-blogs on Consumer Behavioral Intention: A relationship marketing perspective. International Journal of Electronic Business Management, 8(4), 293-303.

Internet World Statistics. (2012). Retrieved from http://www.internetworldstats.com/stats.htm.

Jansen, B. J., Zhang, M., Sobel, K., \& Chowdury, A. (2009). Twitter power: Tweets as electronic word of mouth. Journal of the American Society for Information Science and Technology, 60(11), 2169-2188.

Jasen, B., Zhang, M., Sobel, K., \& Chowdury, A. (2009). Twitter power: Tweets as electronic Word of Mouth. Journal of American Society for Information Science and Technology, 60(11), 2169-2188.

Johnson, T.J., \& Kaye, B.K. (1998). Cruising is believing?: Comparing internet and traditional sources on media credibility measures. Journalism \& Mass Communication Quarterly, $75(2), 325-340$.

Kahle, L.R., \& Homer, P.M. (1985). Physical attractiveness of the celebrity endorser: A social adaptation perspective. Journal of Consumer Research, 3(11), 954-961.

Kang, M. (2010). Measuring social media credibility: A study on a measure of blog credibility. Institute for Public Relations.

Kaplan, A., \& Haenlein, M. (2010). Users of the world, unite! The challenges and opportunities of social media. Business Horizons, 53(1), 59-68.

Karbala, A., Wandebori, H. (2012). Analyzing the factors that affect consumer's purchase intention in Toimoi Store, Indonesia. Proceedings from $2^{\text {nd }}$ International Conference Business, Economics, Management and Behavioral Sciences. Bali, Indonesia. 
Katz, E., \& P. Lazarsfeld. Personal influence. Glencoe, IL: Free Press, 1955.

Keyton, J. (2006). Communication research: Asking questions, finding answers. New York, NY : McGraw- Hill Companies, Inc.

Kim, A.J., \& Ko, E. (2010a). The impact of design characteristics on brand attitude and purchase intention: focus on luxury fashion brands. Journal of the Korean Society for Clothing Industry, 34(2), 252-65.

Kim, A.J., \& Ko, E. (2010b). Impacts of luxury fashion brand's social media marketing on customer relationship and purchase intention. Journal Global Fashion Marketing, 1(3), 164-71.

Kim, A.J., \& Ko, E. (2012). Do social media marketing activities enhance customer equity? An empirical study o luxury fashion brand. Journal of Business Research, 65(10), $1480-1486$.

Kim, H.J., \& Lee, H.Z. (2009). The effect of well-being, consumer value orientations, perceived value and brand preference on purchase intention of environment-friendly cosmetics. Journal of the Korean Society for Clothing Industry, 15(1), 327-48.

Kim, J., Kim, J.E., Johnson, K.K.P. The customer-salesperson relationship and sales effectiveness in luxury fashion stores: the role of self-monitoring. Journal of Global Fashion Marketing, 1(4), 230-9.

Kim, J., McMillan, S.J. (2008). Evaluation of Internet advertising research: a biblimetric analysis 
of citations from key sources. Journal of Advertising, 37(1), P.99-112.

Kim, J., Spielmann, N., McMillan, S.J. (2011). Experience effects on interactivity: functions, processes, and perceptions. Journal of Business Research, 65(2012), 1543-1550.

Kwak, H., Lee, C., \& Moon, S. (2010). What is Twitter, a social network or a news media? In Proceedings of the 19th international conference on World Wide Web- WWW'10, 591-600. New York, NY: ACM Press.

Lafferty, B., \& Goldsmith, R. (1999). Corporate credibility's role in consumers' attitudes and purchase intentions when a high versus a low credibility endorser is used in the ad-recipient's access to attitude-relevant information in memory. Journal of Business Research, 44(2), 109-116.

Lilleker, D.G., \& Malagon, C. (2010). Levels of interactivity in the 2007 French presidential candidates' websites. European Journal of Communication, 25(1), 25-42.

Lipovetsky, G. (1987). L'empire de l'éphémère. Paris: Gal- limard.

Lloyd, A.E., \& Luk, S.T.K. The devil wears Prada or Zara: a revelation into customer perceived value of luxury and mass fashion brands. Journal of Global Fashion Marketing, 1(3), $129-41$.

Macias, W. (2003). A beginning look at the effects of interactivity, product involvement and web experience on comprehension: brand web sites as interactive advertising. Journal of Current Issues \& Research in Advertising, 31-44.

Marketing Made Simple. (n.d.). Word of Mouth, social media and viral advertising. Retrieved 
from

http://www.marketing-made-simple.com/articles/word-of-mouth-advertising.htm\#.U2fhs q1dVtI.

McCracken, G. (1989). Who is the celebrity endorser? cultural foundations of the endorsement process. Journal of Consumer Research, 16(3), 310-321.

McCroskey, J. (1966). Special reports: scales for the measurement of ethos. Speech Monographs, $33(1), 65-72$.

McGuire, W. J. (1985). Attitudes and Attitude Change. In Handbook of Social Psychology, Vol.2. Lindzey, G., \& Aronson, E. New York, NY: Random House.

McMillan, S.J. (2006). Exploring models of interactivity from multiple research traditions: users, documents, systems. The handbook of new media. Updated Student Edition, London. 205-29.

McMillan, S.J., Hwang, J., \& Lee, G. (2003). Effects of structural and perceptual factors on attitudes toward the website. Journal of Advertising Research, 43(4), 400-409.

Mohr, I. (2013). The impact of social media on the fashion industry. The Journal of Applied Business and Economics, 15(2), 17.

Morwitz, V. G., \& Schmittlein, D. (1992). Using segmentation to improve sales forecasts based on purchase intent: Which "intenders" actually buy? Journal of Marketing Research, 29(4), 391-405.

Nielsen. (2012, April 10). Global trust in advertising and brand messages. Retrieved from 
http://www.nielsen.com/us/en/reports/2012/global-trust-in-advertising-and-brand-messag es.html.

Nielsen. (2012, April 10). Consumer trust in online, social and advertising grows. Retrieved from http://www.nielsen.com/us/en/insights/news/2012/consumer-trust-in-online-social-and-m obile-advertising-grows.html.

Ohanian, R. (1990). Construction and validation of a scale to measure celebrity endorsers' perceived expertise, trustworthiness, and attractiveness. Journal of Advertising, 19 (3), 39-52.

Ohanian, R. (1991). The impact of celebrity spokespersons' perceived image on consumers' intention to purchase. Journal of Advertising Research. Feburary/March, 46-54.

O'keefe, D. J. (2002). Persuasion: Theory and research (Vol. 2). Thousand Oaks, CA: Sage Publications.

Orcutt, C. (2012, April 17). Social media: The fashion industry's hottest trend. Retrieved from http://infospace.ischool.syr.edu/2012/04/17/social-media-the-fashion-industrys-hottest-tre $\underline{\mathrm{nd} /}$

O'Reilly, T., \& Battelle, J. (2009). Web Squared: Web 2.0 Five Years.

Patzer, G. L. (1983). Source credibility as a function of communicator physical attractiveness. Journal of Business Research, 11(2), 229-241.

Perlmutter, D. (2008). Blogwars. New York: Oxford.

Piazza, J. (2012, January 28). How much can a celebrity make for tweeting? Retrieved from http://www.vulture.com/2012/01/how-much-can-a-celebrity-make-for-tweeting.html?mid 
=nymag_press.

Rainie, L., \& Duggan, M. (2014, April 30). Heartbleed's Impact. Retrieved from http://usgovinfo.about.com/gi/dynamic/offsite.htm?site=http://www.pewinternet.org/.

Rand, G. (2011). The promise of Mechanical Turk: how online labor markets can help theorists run behavioral experiments. Journal of Theoretical Biology, 03, 004.

Reuters. (2009, June 17). Internet most popular source: poll. Retrieved from http://www.reuters.com/article/2009/06/17/us-media-internet-life-idUSTRE55G4XA200 90617.

Rexrode, C. (2011). Twitter celebrity endorsements are big business for stars and companies. Retrieved from http://www.huffingtonpost.com/2011/11/03/celebrity-twitter-endorsements_n_1073577.h $\underline{\operatorname{tml}}$.

Rice, A., \& Trout, J. (1986). Positioning: the battle for your mind. New York, NY: McGraw Hill Inc.

Roat, O. (2012, July 24). Celebrity endorsements and Twitter: Do we buy things when celebrities tell us to? Retrieved from http://blog.mainstreethost.com/celebrity-endorsements-and-twitter-do-we-buy-things-whe n-celebrities-tell-us-to\#.U2c5ta1dVtI.

Robertson, T.S., \& Gatignon, H. (1986). Competitive effects on technology diffusion. Journal of Marketing, 50(3), 1-12.

Rogers, E. (1971). The diffusion of innovations (second edition, under the name Communication 
of Innovations). New York. Free Press.

Rosner, L., \& Scuncio, J. (2013). NetBase retail report: The buying influence of social channels in fashion. Yahoo Finance. Retrieved from http://finance.yahoo.com/news/netbase-retail-report-buying-influence-130000004.html.

Rubin, A. (2002). The uses-and-gratifications perspective of media effects. In J. Bryant \& D. Zillmann (Eds.), Media effects: Advances in theory and research ( $2^{\text {nd }}$ ed.), 525-548.

Rui, H., Liu, Y., \& Whinston, A. B. (2011). Whose and what chatter matters? The impact of tweets on movie sales. The Impact of Tweets on Movie Sales (October 1, 2011) .NET Institute Working Paper, (11-27).

Rust, R.T., \& Espinoza, F. (2006). How technology advances influence business research and marketing strategy. Journal of Business Research. 59(10-11), 1072-8. New York.

Ryan, A. (2011). Twitter Brings Interactivity to Tweets with “Web Intents.” Retrieved from http://sharocity.com/2011/03/twitter-brings-interactivity-to-tweets-with-web-intents/.

Saffer, A. J., Sommerfeldt, E. J., \& Taylor, M. (2013). The effects of organizational Twitter interactivity on organization-public relationships. Public Relations Review, 39(3), $213-215$

Schiffman, G., \& Kanuk, L. (2000). Consumer Behavior ( $7^{\text {th }}$ ed.). New York, NY: Prentice Hall. Schivinski, B., \& Dąbrowski, D. (2013). The impact of brand communication on brand equity dimensions and brand purchase intention through Facebook. GUT FME Working Paper Series A. Gdansk (Poland): Gdansk University of Technology, Faculty of Management and Economics, 4, 1-24. 
Sicilia, M., Ruiz. S., \& Munuera. J.L. (2005). Effects of interactivity in a web site. Journal of Advertising, 34(3), 31-45.

Sincero, S.M. (2012). Advantages and disadvantages of surveys. Retrieved from https://explorable.com/advantages-and-disadvantages-of-surveys.

Smith, B. G. (2010). Socially distributing public relations: Twitter, Haiti, and interactivity in social media. Public Relations Review, 36(4), 329-335.

Stephenson, L.B. (2009). Fashion brands using Twitter \& social media. Retrieved from http://insidefmm.com/2009/06/womens-wear-daily-social-media-rewrites-fashion/.

Steuer, J. (1992). Defining virtual reality: Dimensions determining telepresence. Journal of Communication, 42(4), 73-93.

Sundar, S., Kalyanaraman, S., \& Brown, J. (2003). Explicating web site interactivity: impression formation effects in political campaign sites. Communication Research, 30(1), 30-59.

Twitter Statistics (2014). Retrieved from http://www.statisticbrain.com/twitter-statistics/.

Twitter Glossary (2014). Retrieved from https://support.twitter.com/articles/166337-the-twitter-glossary.

Valente, T., \& Pumpuang, P. (2007). Identifying opinion leaders to promote behavior change. Health Education \& Behavior, 34, 881- 896.

Vernette, E. (2004). Targeting women's clothing fashion opinion leaders in media planning: an application for magazines. Journal of Advertising Research, 44, 90-107.

Vigneron, F. \& Johnson, L.W. (1999). A review and a conceptual framework of prestige-seeking 
consumer behavior, Academy of Marketing Science Review, 1-15.

Wang, J.S., Cheng, Y.F., \& Chu, Y.L. (2013). Effect of celebrity endorsements on consumer purchase intentions: advertising effect and advertising appeal as mediators. Human Factors and Ergonomics in Manufacturing \& Service Industries, 23(5), 357-367.

Wrench, J.S., Thomas-Maddex, C., Richmond, V.P., \& McCroskey, J.C. (2008). Quantitative research methods for communication. New York, NY: Oxford University Press Inc.

Wu, G., Hu, X., \& Wu, Y. (2010). Effects of perceived interactivity, perceived web assurance and disposition to trust on initial online trust. Journal of Computer-Mediated Communication, 16(1), 1-26.

Wyse, S.E. (2012, November 16). Advantages and disadvantages of surveys. Retrieved from http://www.snapsurveys.com/blog/advantages-disadvantages-surveys/.

Yahr, E. (2013, September 5). Kenneth Cole didn't learn from \#Cairo, posts another controversial tweet. Retrieved from http:/www.washingtonpost.com/blogs/style-blog/wp/2013/09/05/kenneth-cole-didnt-lear n-from-cairo-posts-another-controversial-tweet/.

Yoon, Y. (2005). Examining journalists' perceptions and news coverage of stem cell and cloning organizations. Journalism \& Mass Communication Quarterly, 82(2), 281-300.

Yulihasri., Islam, M.A., \& Daud, K.A.K. Factors that influence customers' buying intention on shopping online. International Journal of Marketing Studies, 3(1), 128-139. 


\section{APPENDIX A - IRB COVER LETTER}

Dear Participant,

This letter is a request for you to take part in a research project to assess how the source type of a fashion industry Twitter message is affecting its perceived source credibility, interactivity and purchase intention. This research is being conducted by Yijia Wang and is for a Master's Degree in Journalism. Your participation in this research is greatly appreciated and will take approximately 15 minutes to fill out the attached questionnaire.

Your involvement in this research will be kept as confidential as legally possible. All data will be reported in the aggregate. You must be 18 years of age or older to participate. I will not ask any information that should lead back to your identity as a participant. Your participation is completely voluntary. You may skip any question that you do not wish to answer and you may discontinue at any time. Your class standing will not be affected if you decide either not to participate or to withdraw. West Virginia University's Institutional Review Board acknowledgement of this project is on file.

I hope that you will participate in this research, as it could be beneficial in understanding the impact of source type in online information communication. Thank you very much for your time. Should you have any questions about this letter or the research research, please feel free to contact Yijia Wang at (304) 282-6660 or by e-mail at yawang@mix.wvu.edu.

Thank you for your time and help with this research.

Sincerely,

Yijia Wang

Perley Isaac Reed School of Journalism, West Virginia University

304-282-6660

yawang@mix.wvu.edu 


\section{APPENDIX B - IRB APPROVAL LETTER}

\section{West VirginiaUniversity.}

Office of Research Integrity and Compliance

\section{Acknowledgement Letter - Exempt - Initial Protocol Review}

To: Geah Preegrove

From: WVU Office of Research Integrity and Compliance

Date: $06 / 06 / 2014$

\section{Subject: Acknowledgement Letter - Exempt - Initial Protocol Review}

Protocol Tracking\#: 1405309637

Title: Fashion Meets Twitter: Does the Source Matter? Perceived Message Credibility, Interactivity and Purchase Intention

The West Virginia University Institutional Review Board approved the above-referenced protocol on 6-Jun-2014. To access this protocol, click on the protocol number link provided. The approval letter can be found in the History subsection of the Summary \& History section located on the Protocol Actions page. For more information, see the Viewing Correspondence quick reference guide. Any future protocol action requests can be completed through WVU+kc.

\section{QUESTIONS?}

Questions related to NHSR, Full Board, Emergency Use, Clinical Trials, or CIRB protocols as well as amendments, renewals, deviations/violations/exceptions, or adverse events/UPIRTSOs should be directed to Lilo Ast at 304.293.7555 or lilo.ast@mail.wvu.edu.

Questions related to Expedited protocols should be directed to Barb White at 304.293.5971 or barb.white@mail.wvu.edu.

Questions related to Exempt protocols, training, or troubleshooting should be directed to Jonathan Young at 304.293.1119 or jonathan.young@mail.wvu.edu. 


\section{APPENDIX C -INFORMED CONSENT STATEMENT}

Thank you for agreeing to participate in this survey. For planning purposes, participation should take approximately 10 to 25 minutes of your time. It is important that once you begin you have allocated sufficient time to answer all questions because partially completed questionnaires cannot be used.

This study is being conducted by a master student at West Virginia University. The purpose of this research is to better understand the relationship between different types of sources of a fashion industry Twitter message and its perceived source credibility, consumers' engagement with the message and purchase intention.

Before you begin, please read the information below and indicate whether you agree to participate in this study. Your participation is voluntary, but in appreciation of your time, 20 cents will be given as reward.

The research should not put you in any unusual risk. A committee that works to protect your rights and welfare reviews all research on human volunteers. West Virginia University's Institutional Review Board (IRB) has acknowledgment of this study on file. If you have questions on concerns about your rights as a research subject, you may contact, anonymously if you wish, the IRB at (304) 293-7073 or Johnathan.Young@mail.wvu.edu.

All of your responses within the context of this study are completely confidential to ensure your privacy. No information will be attributed to any participant in the final manuscript. Results of each question will be complied electronically by MTurk, the online survey system.

As this study is focused on the fashion industry and Twitter, participants should be interested in fashion and have an account on Twitter.

By continuing, you are indicated that you are over the age of 18, and wish to participate in this study. 


\section{APPENDIX D -SURVEY INSTRUMENT}

Q1 For the purpose of this study, the concept of fashion is not limited to any particular vogue style, brand, trend, fad or craze. Instead, fashion refers to any clothing, footwear, accessories, make-up, etc. that you believe matches your personal style. Before proceeding, please indicate your level of interest in fashion as it relates to your own personal style.

Not At All Interested (1)

Not Very Interested (2)

Somewhat Interested (3)

Very Interested (4)

If Not At All Interested Is Selected, Then Skip To End of Survey

Q2 Please indicate if you use Twitter.

O Yes (1)

No (2)

If No Is Selected, Then Skip To End of Survey

Q3 Instructions: For the items that follow, rating scales with 5 places are provided. For example, if you were asked to rate "The scenery of West Virginia," the 5 places should be interpreted as follows: The natural scenery of West Virginia is:

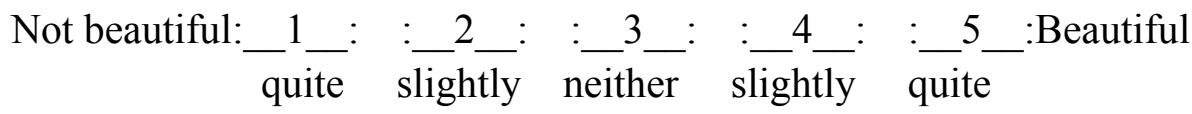


Q4 First think about one fashion brand that you like or admire. Now consider if you saw a tweet from its official Twitter account relating to the latest fashion trends or apparel for the upcoming season. With this in mind, look at the following adjective pairs and indicate your rating of the official brand as a source for fashion information.

\begin{tabular}{|c|c|c|c|c|c|}
\hline & $1(1)$ & $2(2)$ & $3(3)$ & $4(4)$ & $5(5)$ \\
\hline Inexpert:Expert (1) & $\mathrm{O}$ & $\mathrm{O}$ & $\mathrm{O}$ & $\mathrm{O}$ & $\mathrm{O}$ \\
\hline Inexperienced:Experienced (2) & $\mathrm{O}$ & $\mathrm{O}$ & $\mathrm{O}$ & $\mathrm{O}$ & $\mathrm{O}$ \\
\hline $\begin{array}{l}\text { Unknowledgeable:Knowledgeable } \\
\text { (3) }\end{array}$ & O & $\mathrm{O}$ & $\mathrm{O}$ & $\mathrm{O}$ & O \\
\hline Unqualified:Qualified (4) & O & O & O & O & O \\
\hline Unskilled:Skilled (5) & O & $\mathrm{O}$ & $\mathrm{O}$ & $\mathrm{O}$ & O \\
\hline Unfriendly:Friendly (6) & O & $\mathrm{O}$ & $\mathrm{O}$ & $\mathrm{O}$ & O \\
\hline Unpleasant:Pleasant (7) & O & O & $\mathrm{O}$ & O & O \\
\hline Unselfish:Selfish (8) & O & O & $\mathrm{O}$ & O & O \\
\hline Awful:Nice (9) & O & O & $\mathrm{O}$ & $\mathrm{O}$ & O \\
\hline Sinful:Virtuous (10) & O & O & $\mathrm{O}$ & O & O \\
\hline Unattractive:Attractive (11) & O & O & $\mathrm{O}$ & O & O \\
\hline Styleless:Classy (12) & O & O & O & O & O \\
\hline Not beautiful:Beautiful (13) & O & O & O & O & O \\
\hline Not elegant:Elegant (14) & O & O & O & O & O \\
\hline Not sexy:Sexy (15) & O & O & O & O & $\mathrm{O}$ \\
\hline Not dependable:Dependable (16) & O & O & $\mathrm{O}$ & $\mathrm{O}$ & O \\
\hline Untrustworthy:Trustworthy (17) & O & $\mathrm{O}$ & O & O & O \\
\hline Unreliable:Reliable (18) & O & O & O & O & O \\
\hline Dishonest:Honest (19) & O & O & $\mathrm{O}$ & O & O \\
\hline Insincere:Sincere (20) & O & O & $\mathrm{O}$ & O & O \\
\hline Not influential:Influential (21) & O & O & $\mathrm{O}$ & $\mathrm{O}$ & O \\
\hline Without passion:Passionate (22) & O & O & O & $\mathrm{O}$ & O \\
\hline Not transparent:Transparent (23) & 0 & 0 & O & O & $\mathrm{O}$ \\
\hline
\end{tabular}


Q5 Based on the brand's tweet, how likely would you be to...

\begin{tabular}{|c|c|c|c|c|c|}
\hline & $\begin{array}{c}\text { Very } \\
\text { Unlikely (1) }\end{array}$ & $\begin{array}{l}\text { Somewhat } \\
\text { Unlikely (2) }\end{array}$ & $\begin{array}{r}\text { Neither } \\
\text { Likely, nor } \\
\text { unlikely (3) }\end{array}$ & $\begin{array}{l}\text { Somewhat } \\
\text { likely (4) }\end{array}$ & $\begin{array}{r}\text { Very } \\
\text { Likely (5) }\end{array}$ \\
\hline $\begin{array}{l}\ldots \text { follow the } \\
\text { brand } \\
\text { mentioned? (1) }\end{array}$ & 0 & 0 & 0 & 0 & 0 \\
\hline $\begin{array}{l}\text {...reply to this } \\
\text { tweet? (2) }\end{array}$ & 0 & O & 0 & 0 & 0 \\
\hline $\begin{array}{l}\text {...reTweet this } \\
\text { tweet (3) }\end{array}$ & 0 & O & 0 & 0 & O \\
\hline $\begin{array}{l}\ldots \text { favorite this } \\
\text { tweet? (4) }\end{array}$ & 0 & O & 0 & 0 & O \\
\hline $\begin{array}{l}\ldots \text { send direct } \\
\text { message to this } \\
\text { account if you } \\
\text { have } \\
\text { question or } \\
\text { comment? (5) }\end{array}$ & 0 & 0 & 0 & 0 & 0 \\
\hline $\begin{array}{l}\ldots \text { share a } \\
\text { modified } \\
\text { tweet? (6) }\end{array}$ & 0 & 0 & 0 & 0 & 0 \\
\hline $\begin{array}{l}\ldots \text { share this } \\
\text { tweet outside } \\
\text { of Twitter? (7) }\end{array}$ & O & 0 & 0 & O & O \\
\hline $\begin{array}{l}\ldots \\
\text { online fearch } \\
\text { more } \\
\text { information } \\
\text { about the } \\
\text { fashion. (8) }\end{array}$ & 0 & O & 0 & 0 & O \\
\hline
\end{tabular}


Q6 Based on the brand's tweet, I am likely to purchase this product ...

\begin{tabular}{|c|c|c|c|c|c|}
\hline & $\begin{array}{c}\text { Very } \\
\text { Unlikely (1) }\end{array}$ & $\begin{array}{l}\text { Somewhat } \\
\text { Unlikely (2) }\end{array}$ & $\begin{array}{r}\text { Neither } \\
\text { Likely, nor } \\
\text { unlikely (3) }\end{array}$ & $\begin{array}{l}\text { Somewhat } \\
\text { likely (4) }\end{array}$ & $\begin{array}{r}\text { Very } \\
\text { Likely (5) }\end{array}$ \\
\hline $\begin{array}{l}\ldots \text { if it is } \\
\text { priced } \\
\text { reasonably or } \\
\text { is affordable. } \\
\text { (1) }\end{array}$ & 0 & 0 & 0 & 0 & 0 \\
\hline $\begin{array}{l}\ldots \text { if it is easy } \\
\text { to buy online } \\
\text { right that } \\
\text { moment. (2) }\end{array}$ & 0 & O & O & 0 & 0 \\
\hline $\begin{array}{l}\ldots \text { later at a } \\
\text { store or online. } \\
\text { (3) }\end{array}$ & O & 0 & 0 & 0 & 0 \\
\hline $\begin{array}{l}\ldots \text { if I am in } \\
\text { need of a new } \\
\text { outfit for an } \\
\text { upcoming } \\
\text { event or } \\
\text { occasion. (4) }\end{array}$ & 0 & O & 0 & 0 & 0 \\
\hline $\begin{array}{l}\ldots \text { if it appears } \\
\text { to be a great } \\
\text { value. (5) }\end{array}$ & 0 & 0 & 0 & 0 & 0 \\
\hline $\begin{array}{l}\ldots \text { if it } \\
\text { compliments } \\
\text { my personal } \\
\text { sense of style. } \\
\text { (6) }\end{array}$ & 0 & 0 & 0 & 0 & 0 \\
\hline $\begin{array}{l}\ldots \text { if it looks } \\
\text { like something } \\
\text { that my group } \\
\text { of friends and I } \\
\text { might normally } \\
\text { wear. (7) }\end{array}$ & 0 & 0 & 0 & 0 & 0 \\
\hline
\end{tabular}


Q7 For the second possible source of a fashion message, please think about a good friend, or an acquaintance whose sense of fashion you admire. Now consider if you saw a tweet from $\mathrm{him} / \mathrm{her}$ relating to the latest fashion trends or apparel for the upcoming season. With this in mind, look at the following adjective pairs and indicate your rating of the friend or acquaintance as a source for fashion information.

\begin{tabular}{|c|c|c|c|c|c|}
\hline & $1(1)$ & $2(2)$ & $3(3)$ & $4(4)$ & $5(5)$ \\
\hline Inexpert:Expert (1) & O & O & $\mathrm{O}$ & $\mathrm{O}$ & O \\
\hline Inexperienced:Experienced (2) & $\mathrm{O}$ & $\mathrm{O}$ & $\mathrm{O}$ & $\mathrm{O}$ & O \\
\hline $\begin{array}{l}\text { Unknowledgeable:Knowledgeable } \\
\text { (3) }\end{array}$ & O & O & $\mathrm{O}$ & O & O \\
\hline Unqualified:Qualified (4) & O & $\mathrm{O}$ & O & O & O \\
\hline Unskilled:Skilled (5) & O & O & $\mathrm{O}$ & $\mathrm{O}$ & O \\
\hline Unfriendly:Friendly (6) & O & O & $\mathrm{O}$ & $\mathrm{O}$ & O \\
\hline Unpleasant:Pleasant (7) & O & O & $\mathrm{O}$ & O & O \\
\hline Unselfish:Selfish (8) & O & O & $\mathrm{O}$ & O & O \\
\hline Awful:Nice (9) & O & O & $\mathrm{O}$ & $\mathrm{O}$ & O \\
\hline Sinful:Virtuous (10) & O & O & O & O & O \\
\hline Unattractive:Attractive (11) & O & O & O & O & O \\
\hline Styleless:Classy (12) & O & O & O & O & O \\
\hline Not beautiful:Beautiful (13) & O & O & O & O & O \\
\hline Not elegant:Elegant (14) & O & O & O & O & O \\
\hline Not sexy:Sexy (15) & O & O & O & O & O \\
\hline Not dependable:Dependable (16) & O & O & $\mathrm{O}$ & $\mathrm{O}$ & O \\
\hline Untrustworthy:Trustworthy (17) & O & $\mathrm{O}$ & O & O & O \\
\hline Unreliable:Reliable (18) & O & O & O & O & O \\
\hline Dishonest:Honest (19) & O & O & $\mathrm{O}$ & O & O \\
\hline Insincere:Sincere (20) & O & O & $\mathrm{O}$ & O & O \\
\hline Not influential:Influential (21) & O & O & O & O & O \\
\hline Without passion:Passionate (22) & O & O & O & O & O \\
\hline Not transparent:Transparent (23) & 0 & 0 & 0 & 0 & 0 \\
\hline
\end{tabular}


Q8 Based on the friend or acquaintance's tweet, how likely would you be to...

\begin{tabular}{|c|c|c|c|c|c|}
\hline & $\begin{array}{c}\text { Very } \\
\text { Unlikely (1) }\end{array}$ & $\begin{array}{l}\text { Somewhat } \\
\text { Unlikely (2) }\end{array}$ & $\begin{array}{r}\text { Neither } \\
\text { Likely, nor } \\
\text { unlikely (3) }\end{array}$ & $\begin{array}{l}\text { Somewhat } \\
\text { likely (4) }\end{array}$ & $\begin{array}{r}\text { Very } \\
\text { Likely (5) }\end{array}$ \\
\hline $\begin{array}{l}\ldots \text { follow the } \\
\text { brand } \\
\text { mentioned? (1) }\end{array}$ & O & 0 & O & 0 & 0 \\
\hline $\begin{array}{l}\text {...reply to this } \\
\text { tweet? ( } 2)\end{array}$ & O & 0 & 0 & 0 & 0 \\
\hline $\begin{array}{l}\text {...reTweet this } \\
\text { tweet ( } 3 \text { ) }\end{array}$ & 0 & 0 & 0 & 0 & 0 \\
\hline $\begin{array}{l}\ldots \text { favorite this } \\
\text { tweet? (4) }\end{array}$ & 0 & 0 & 0 & 0 & 0 \\
\hline $\begin{array}{l}\text {... send direct } \\
\text { message to this } \\
\text { account if you } \\
\text { have a } \\
\text { question or } \\
\text { comment? (5) }\end{array}$ & 0 & 0 & 0 & 0 & 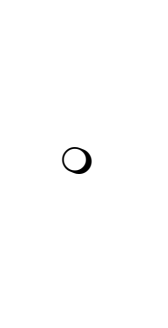 \\
\hline $\begin{array}{l}\ldots \text { share a } \\
\text { modified } \\
\text { tweet? (6) }\end{array}$ & O & 0 & 0 & 0 & 0 \\
\hline $\begin{array}{l}\ldots \text { share this } \\
\text { tweet outside } \\
\text { of Twitter? (7) }\end{array}$ & 0 & 0 & 0 & 0 & 0 \\
\hline $\begin{array}{l}\text {... search } \\
\text { online for } \\
\text { more } \\
\text { information } \\
\text { about the } \\
\text { fashion. (8) }\end{array}$ & 0 & 0 & 0 & 0 & 0 \\
\hline
\end{tabular}


Q9 Based on the friend or acquaintance's tweet, I am likely to purchase this product ...

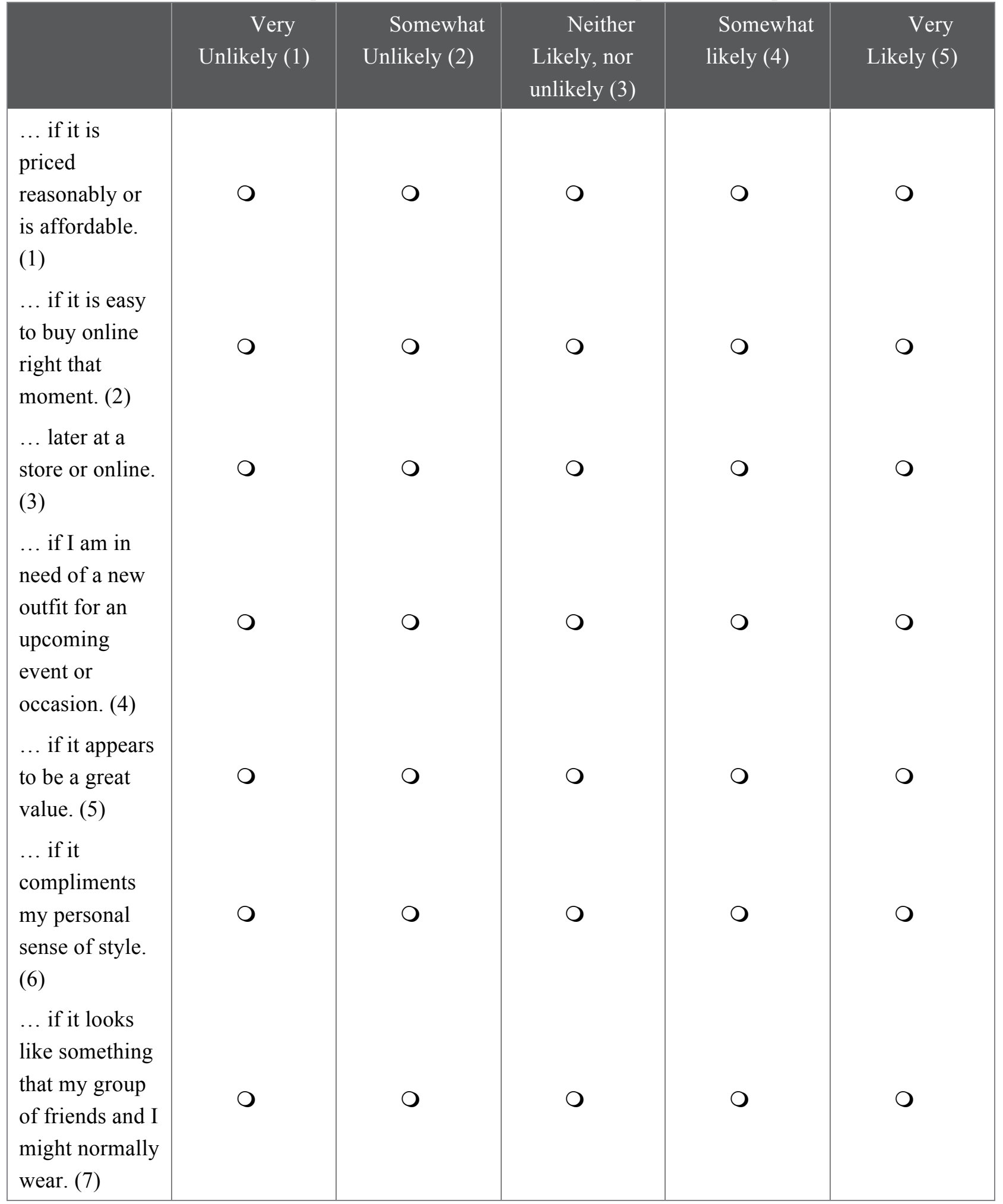


Q10 For the final possible source of a fashion message, please think about your favorite celebrity, or a celebrity whose sense of fashion you admire. Now consider if you saw a tweet from $\mathrm{him} / \mathrm{her}$ relating to the latest fashion trends or apparel for the upcoming season. With this in mind, look at the following adjective pairs and indicate your rating of the celebrity as a source for fashion information.

\begin{tabular}{|c|c|c|c|c|c|}
\hline & $1(1)$ & $2(2)$ & $3(3)$ & $4(4)$ & $5(5)$ \\
\hline Inexpert:Expert (1) & $\mathrm{O}$ & $\mathrm{O}$ & $\mathrm{O}$ & $\mathrm{O}$ & $\mathrm{O}$ \\
\hline Inexperienced:Experienced (2) & $\mathrm{O}$ & $\mathrm{O}$ & $\mathrm{O}$ & $\mathrm{O}$ & $\mathrm{O}$ \\
\hline $\begin{array}{l}\text { Unknowledgeable:Knowledgeable } \\
\text { (3) }\end{array}$ & $\mathrm{O}$ & $\mathrm{O}$ & $\mathrm{O}$ & $\mathrm{O}$ & $\mathrm{O}$ \\
\hline Unqualified:Qualified (4) & $\mathrm{O}$ & $\mathrm{O}$ & $\mathrm{O}$ & $\mathrm{O}$ & $\mathrm{O}$ \\
\hline Unskilled:Skilled (5) & $\mathrm{O}$ & $\mathrm{O}$ & $\mathrm{O}$ & $\mathrm{O}$ & $\mathrm{O}$ \\
\hline Unfriendly:Friendly (6) & $\mathrm{O}$ & $\mathrm{O}$ & $\mathrm{O}$ & $\mathrm{O}$ & $\mathrm{O}$ \\
\hline Unpleasant:Pleasant (7) & $\mathrm{O}$ & $\mathrm{O}$ & $\mathrm{O}$ & $\mathrm{O}$ & $\mathrm{O}$ \\
\hline Unselfish:Selfish (8) & $\mathrm{O}$ & $\mathrm{O}$ & $\mathrm{O}$ & $\mathrm{O}$ & $\mathrm{O}$ \\
\hline Awful:Nice (9) & $\mathrm{O}$ & $\mathrm{O}$ & $\mathrm{O}$ & $\mathrm{O}$ & $\mathrm{O}$ \\
\hline Sinful:Virtuous (10) & $\mathrm{O}$ & $\mathrm{O}$ & $\mathrm{O}$ & $\mathrm{O}$ & $\mathrm{O}$ \\
\hline Unattractive:Attractive (11) & $\mathrm{O}$ & $\mathrm{O}$ & $\mathrm{O}$ & $\mathrm{O}$ & $\mathrm{O}$ \\
\hline Styleless:Classy (12) & $\mathrm{O}$ & $\mathrm{O}$ & $\mathrm{O}$ & $\mathrm{O}$ & $\mathrm{O}$ \\
\hline Not beautiful:Beautiful (13) & $\mathrm{O}$ & $\mathrm{O}$ & $\mathrm{O}$ & $\mathrm{O}$ & $\mathrm{O}$ \\
\hline Not elegant:Elegant (14) & $\mathrm{O}$ & $\mathrm{O}$ & $\mathrm{O}$ & $\mathrm{O}$ & $\mathrm{O}$ \\
\hline Not sexy:Sexy (15) & $\mathrm{O}$ & $\mathrm{O}$ & $\mathrm{O}$ & $\mathrm{O}$ & $\mathrm{O}$ \\
\hline Not dependable:Dependable (16) & O & O & $\mathrm{O}$ & $\mathrm{O}$ & O \\
\hline Untrustworthy:Trustworthy (17) & O & $\mathrm{O}$ & $\mathrm{O}$ & $\mathrm{O}$ & $\mathrm{O}$ \\
\hline Unreliable:Reliable (18) & O & O & $\mathrm{O}$ & O & O \\
\hline Dishonest:Honest (19) & O & O & $\mathrm{O}$ & O & O \\
\hline Insincere:Sincere (20) & O & O & $\mathrm{O}$ & O & O \\
\hline Not influential:Influential (21) & O & $\mathrm{O}$ & $\mathrm{O}$ & O & O \\
\hline Without passion:Passionate (22) & O & $\mathrm{O}$ & $\mathrm{O}$ & O & O \\
\hline Not transparent:Transparent (23) & $\mathrm{O}$ & $\mathrm{O}$ & $\mathrm{O}$ & $\mathrm{O}$ & $\mathrm{O}$ \\
\hline
\end{tabular}


Q11 Based on the celebrity's tweet, how likely would you be to...

\begin{tabular}{|c|c|c|c|c|c|}
\hline & $\begin{array}{c}\text { Very } \\
\text { Unlikely (1) }\end{array}$ & $\begin{array}{l}\text { Somewhat } \\
\text { Unlikely (2) }\end{array}$ & $\begin{array}{r}\text { Neither } \\
\text { Likely, nor } \\
\text { unlikely (3) }\end{array}$ & $\begin{array}{l}\text { Somewhat } \\
\text { likely (4) }\end{array}$ & $\begin{array}{r}\text { Very } \\
\text { Likely (5) }\end{array}$ \\
\hline $\begin{array}{l}\ldots \text { follow the } \\
\text { brand } \\
\text { mentioned? (1) }\end{array}$ & 0 & 0 & O & 0 & O \\
\hline $\begin{array}{l}\text {...reply to this } \\
\text { tweet? (2) }\end{array}$ & O & 0 & O & 0 & O \\
\hline $\begin{array}{l}\text {...reTweet this } \\
\text { tweet (3) }\end{array}$ & O & 0 & 0 & 0 & O \\
\hline $\begin{array}{l}\text {... favorite this } \\
\text { tweet? (4) }\end{array}$ & 0 & 0 & 0 & 0 & 0 \\
\hline $\begin{array}{l}\ldots \text { send direct } \\
\text { message to this } \\
\text { account if you } \\
\text { have a } \\
\text { question or } \\
\text { comment? (5) }\end{array}$ & 0 & 0 & 0 & 0 & 0 \\
\hline $\begin{array}{l}\ldots \text { share a } \\
\text { modified } \\
\text { tweet? (6) }\end{array}$ & 0 & 0 & 0 & 0 & 0 \\
\hline $\begin{array}{l}\ldots \text { share this } \\
\text { tweet outside } \\
\text { of Twitter? (7) }\end{array}$ & 0 & 0 & 0 & 0 & O \\
\hline $\begin{array}{l}\text {... search } \\
\text { online for } \\
\text { more } \\
\text { information } \\
\text { about the } \\
\text { fashion. (8) }\end{array}$ & O & 0 & 0 & 0 & O \\
\hline
\end{tabular}


Q12 Based on the celebrity\&\#39; tweet, I am likely to purchase this product ...

\begin{tabular}{|c|c|c|c|c|c|}
\hline & $\begin{array}{c}\text { Very } \\
\text { Unlikely (1) }\end{array}$ & $\begin{array}{l}\text { Somewhat } \\
\text { Unlikely (2) }\end{array}$ & $\begin{array}{r}\text { Neither } \\
\text { Likely, nor } \\
\text { unlikely (3) }\end{array}$ & $\begin{array}{l}\text { Somewhat } \\
\text { likely (4) }\end{array}$ & $\begin{array}{r}\text { Very } \\
\text { Likely (5) }\end{array}$ \\
\hline $\begin{array}{l}\ldots \text { if it is } \\
\text { priced } \\
\text { reasonably or } \\
\text { is affordable. } \\
\text { (1) }\end{array}$ & O & O & 0 & 0 & O \\
\hline $\begin{array}{l}\ldots \text { if it is easy } \\
\text { to buy online } \\
\text { right that } \\
\text { moment. (2) }\end{array}$ & 0 & 0 & 0 & 0 & 0 \\
\hline $\begin{array}{l}\ldots \text { later at a } \\
\text { store or online. } \\
\text { (3) }\end{array}$ & 0 & 0 & O & 0 & O \\
\hline $\begin{array}{l}\ldots \text { if I am in } \\
\text { need of a new } \\
\text { outfit for an } \\
\text { upcoming } \\
\text { event or } \\
\text { occasion. (4) }\end{array}$ & 0 & 0 & 0 & 0 & O \\
\hline $\begin{array}{l}\ldots \text { if it appears } \\
\text { to be a great } \\
\text { value. (5) }\end{array}$ & O & 0 & 0 & 0 & O \\
\hline $\begin{array}{l}\ldots \text { if it } \\
\text { compliments } \\
\text { my personal } \\
\text { sense of style. } \\
\text { (6) } \\
\ldots \text { if it looks } \\
\text { like something } \\
\text { that my group } \\
\text { of friends and I } \\
\text { might normally } \\
\text { wear. (7) }\end{array}$ & 0 & 0 & 0 & 0 & 0 \\
\hline
\end{tabular}


Q13 Please tell us a bit more about how you make fashion purchase decisions and the role of Twitter in the decision-making process. For what reasons are you most likely to purchase fashion apparel? Please pick the one that best applies, or write your own reason in the space provided.

As a form of self expression (1)

To fit in with my friends (2)

I don't care about fashion (3)

I only buy fashion apparel for special occasions (4)

Other. Please specify (5)

Q14 Of the following Twitter sources, which ONE do you think is the most credible in providing fashion information?

Brand's official account (1)

Celebrity as brand endorser (2)

Friend or relatives' recommendation (3)

Other. Please specify (4)

Q15 Of the following Twitter sources, which ONE are you most likely to turn to when seeking fashion information?

Brand's official account (1)

Celebrity as brand endorser (2)

Friend or relatives' recommendation (3)

Other. Please specify (4)

Q16 Only a few more questions now. To better understand the participants in this study, could you please tell us a little about yourself and your online habits. Which social media platform do you use most often?

Facebook (1)

Twitter (2)

YouTube (3)

Instagram (4)

Other. Please specify (5) 
Q17 On average, approximately how many hours do you spend on social media each day?

O Never (1)

O Less than 1 hour (2)

O 1 hour to 3 hours (3)

3 hours to 6 hours (4)

O More than 6 hours (5)

Q18 Approximately how many followers do you have on Twitter?

O None (2)

O Less than $100(3)$

O Between 101 and 500 (4)

O Between 501 and 1000 (5)

O More than 1000 (6)

Q19 Your gender is

O Male (1)

O Female (2)

Decline to answer (3)

Q20 What is your age?

O $18-25(1)$

O 26-35 (2)

O $36-45$ (3)

O $46-55$ (4)

O $56+(5)$

Q21 How would you describe your current employment status?

O Employed full-time (1)

O Employed part-time (2)

O Independent contractor/Self-employed (3)

O Unemployed (4)

O Looking for work (5)

O Student (6)

O Stay-at-home parent (7)

O Retired (8) 
Q22 How much would you estimate your 2014 household income will be before taxes?

O Under $\$ 25,000(1)$

O $\$ 25,000-\$ 39,999(2)$

O $\$ 40,000-\$ 49,999(3)$

O $\$ 50,000-\$ 74,999(4)$

O $\$ 75,000-\$ 99,999(5)$

O $\$ 100,000-\$ 124,999(6)$

O $\$ 125,000-\$ 149,999(7)$

O More than $\$ 150,000(8)$

Q23 What is the highest degree or level of school you have completed or are currently enrolled in?

O No school completed (1)

O Junior middle school graduate (2)

O High school graduate (3)

O Some college credits (4)

O Bachelor's degree (including currently enrolled) (5)

O Master's degree (including currently enrolled) (6)

O Doctorate degree (including currently enrolled) (7)

Q24 Thank you for participating in this study. Do you have any thoughts, suggestions, or comments related to the study that you would like to share? If so, please add them in the box provided. 